\title{
Suvremena migracijska obilježja statističkih jedinica Republike Hrvatske
}

DOI: $10.11567 /$ met.30.3.7

UDK: 314.7:35](497.5)"2001/2011"

Prethodno priopćenje

Primljeno: 30.112014.

Prihvaćeno: 9.1.2015.

\section{Sanja Klempić Bogadi}

Institut za migracije i narodnosti, Zagreb

sanja.klempic@imin.hr

\section{Ivan Lajić}

Institut za migracije i narodnosti, Zagreb

ivan.lajic@imin.hr

\section{SAŽETAK}

U članku se analiziraju osnovni demografski procesi u Republici Hrvatskoj (NUTS 1), u njenim statističkim makroregijama (NUTS 2) i županijama (NUTS 3) u međupopisnom razdoblju 2001. - 2011. U teorijskom dijelu raspravlja se o optimalnom ustroju i uspostavi statističkih makroregija te o utjecaju demografskih čimbenika na njihovo formiranje. Autori se kritički postavljaju prema kvaliteti i sadržaju pojedinih demografskih kategorija u posljednjem popisu stanovništva te njegovoj neusporedivosti s prethodnim popisima. I nadalje je prisutna depopulacija srednjeg intenziteta, međutim teritorijalno veliki dio hrvatskog prostora zahvaćen je tim nepovoljnim obilježjem općega kretanja. Naime samo su Grad Zagreb i Zagrebačka županija u Kontinentalnoj Hrvatskoj u posljednjemu desetljetnome međupopisnom razdoblju zabilježili porast broja stanovnika, dok je u Jadranskoj Hrvatskoj takav slučaj samo u Zadarskoj i Istarskoj županiji. Obje sastavnice općega kretanja stanovništva Hrvatske, prirodno kretanje i migracijski saldo, imaju negativni predznak. Od 21 NUTS 3 jedinice samo su dvije imale prirodni prirast (Splitsko-dalmatinska i Dubrovačko-neretvanska), dok su ostale županije, pa čak i imigracijske, registrirale prirodni pad stanovništva. Iz migracijskih podataka očito je da se Hrvatska demografski polarizirala na Zagreb i okolicu kao gospodarsko i demografsko središte države te na priobalne županije, koje gospodarski razvoj i donekle migracijsku atraktivnost uglavnom temelje na još uvijek ekonomski atraktivnom turizmu. Većina županija Kontinentalne Hrvatske čini slabo razvijena, periferna područja depopulacije i općenito demografskog nazadovanja.

KLJUČNE RIJEČI: Hrvatska, NUTS, migracija, depopulacija, prirodna promjena 


\section{UVOD}

Čitavo desetljeće, najavom, a potom i etapama približavanja Republike Hrvatske članstvu u Europskoj uniji, odvijala se stručna, politička i znanstvena rasprava o optimalnoj statističkoj (neadministrativnoj) regionalizaciji Hrvatske. Ona je u proteklom razdoblju rezultirala različitim prijedlozima razdiobe, da bi se na kraju usvojila dvoregionalna statistička podjela hrvatskog teritorija. Valja istaknuti da je svaka članica Europske unije i njezina pristupnica bila dužna provesti statističku podjelu teritorija obvezujući se slijediti hijerarhijske kriterije uspostave statističkih jedinica triju rangova NUTS 1, NUTS 2 i NUTS 3. ${ }^{1}$ Kao statistička jedinica NUTS 1 obuhvaćen je cjelokupni državni teritorij, a kao NUTS 2 formiraju se dvije neadministrativne statističke jedinice: Jadranska Hrvatska i Kontinentalna Hrvatska. Premda nose naziv neadministrativne regije, one su nastale agregiranjem administrativnih jedinica, županija, koje se u Hrvatskoj ujedno smatraju regijama najnižeg ranga - NUTS 3.

Jedan od temeljnih kriterija uspostave ranga neadministrativne regije jest demografski okvir, a kao i svaku regiju, i administrativne regije moraju obilježavati ključni elementi: »struktura, procesi i međuodnosi« (Njegač, 2000: 191). Smatramo da ti ključni elementi trebaju biti predmet demografske analize. Broj stanovnika kao kriterij uspostave pojedine regije ovisi o dvije sastavnice: prirodnom kretanju i migracijama. Demografska dimenzija regije mijenja se i tako pred svaku državu članicu u dogledno vrijeme stavlja nove mogućnosti za rekonstrukciju regionalne strukture koja prvenstveno može utjecati na financijski odnos prema fondovima EU-a. Osim što demografski okvir neposredno predstavlja okvir definiranja NUTS regije, promjena broja stanovnika pojedinog područja utječe i na vrlo značajni funkcionalni pokazatelj pristupa određenim sredstvima EU-a, BDP po stanovniku. On se mijenja ne samo s fizičkim promjenama brojnika pokazatelja, tj. BDP-om pojedinog područja, već i s promjenom nazivnika, tj. brojem stanovnika.

\section{Problematika hrvatskih NUTS regija}

Utemeljenje statističkih regija Hrvatske izazvalo je daleko više oprečnih stavova nego što je to slučaj s bilo kojom drugom regionalizacijom državnog prostora. ${ }^{2}$ Postavlja se pitanje zašto je došlo do tolike stručne diskrepancije,

Uredba (EZ) br. 1059/2003 Europskog parlamenta i Vijeća od 26. svibnja 2003. o uspostavi zajedničke klasifikacije prostornih jedinica za statistiku (NUTS).

2 Sustav prostornih jedinica za statistiku EU-a utemeljen je s ciljem kvalitetnijeg uspoređivanja regija unutar zemalja članica EU-a, a jedinice su definirane isključivo u statističke 
isključivo u domeni opredjeljenja NUTS 2 jedinica. Razloge možemo podijeliti na objektione i subjektione.

Hrvatska je gotovo povijesno osjetljiva na pojam regionalizacije ${ }^{3}$. Ona nosi političke konotacije jer Hrvatska u svojoj prošlosti najčešće nije bila homogen političko-administrativni prostor. Glavnina Jadranske Hrvatske pripadala je Mletačkoj Republici, a potom su je bilo parcijalno, bilo u cijelosti okupirali Talijani. Ostala Hrvatska, bez obzira na izvjesni stupanj političke autonomije, bila je pod vlašću Austrije ili Austro-Ugarske, a njeni dijelovi (primjerice Baranja) nisu se nalazili u sklopu Banske Hrvatske i Slavonije. I nakon svih tih povijesnih razdioba i dominacije tuđinske vlasti pred $\mathrm{Hr}-$ vatsku se stavlja zadatak nove regionalizacije, koju mnogi intuitivno vežu uz traume prošlosti i bojazan od novih dioba (»autonomaštvo«, »krajina« itd.), ali i strah od novog oblika centralizacije, odnosno dominacije, ovaj put Zagreba.

Valja istaknuti da se ovaj oblik »regionalizacije«, kao što je bio slučaj i u većini zemalja EU-a, prvi put provodi kod nas, pa je pomanjkanje iskustva

svrhe, kako bi se prikupili što sadržajniji i kvalitetniji podaci na tri spoznajne, hijerarhijski postavljene razine NUTS 1, NUTS 2 i NUTS 3. Zemljama članicama prepušteno je da za svoje potrebe razviju i dodatne niže razine NUTS jedinica (NUTS 4 i NUTS 5). U prvo vrijeme sve hijerarhijske čestice bile su označene kraticom NUTS (franc. Nomenclature des unités territoriales statistiques, Nomenklatura prostornih jedinica za statistiku), da bi potom peterostruka NUTS razdioba bila svedena na tri razine NUTS-a, dok su lokalne upravne jedinice dobile oznaku LAU 1 i LAU 2 (Local Administrative Units). Bez obzira na to što se statističke prostorne jedinice višeg ranga trebaju definirati aplikacijom višeznačnih kriterija (homogenost regije, povijesna sličnost ostalim regijama, odnosno različitost od njih, prirodno-geografska sličnost itd.), u literaturi vezanoj uz tu problematiku kao čvrsti kriterij rangiranja statističkih jedinica višeg ranga (NUTS 1, NUTS 2 i NUTS 3) ističe se samo demografski obujam jedinica. Tako jedinica NUTS 1 obuhvaća broj stanovnika od tri do sedam milijuna. Smatramo da je unutar klasifikacijskog sustava ključna statistička jedinica NUTS 2. Naime razdiobom ukupnog teritorija (NUTS 1) na niže rangirane regije (NUTS 2) mogu se kratkoročno i srednjoročno regulirati odnosi između pojedinih regija, a u konačnici i odnos cijele države prema razini sufinanciranja određenih projekata i financijske potpore EU-a. No uspostava NUTS 2 regije treba ispuniti demografski okvir, a to je broj stanovnika između 800.000 i 3.000.000, te slijediti već spomenute određene geografske, povijesne, kulturne i ostale kriterije. Kada se govori o NUTS kategorijama, valja imati na umu da je njihovo definiranje vrlo fleksibilno te načela Eurostata koja se odnose na njihovu uspostavu daju mogućnost članicama EU-a da čak svake treće godine preispitaju svoj regionalni ustroj. Sljedeća su niža statistička razina NUTS 3 podregije. Njihovo donošenje isključivo je u nadležnosti državne vlasti, a preporuka je da broj njihovih stanovnika bude između 150.000 i 800.000 .

3 »Gdje su korijeni straha i otpora prema regionalizmu u nas a gdje su korijeni političke regionalizacije? Bez duljeg ulaženja u povijest i problem može se reći da je veći dio hrvatske povijesti bio povezan s drugima i da su jednim dijelom povijesti u različitim dijelovima postojali različiti gospodari. Strah od dioba kojima su pribjegavale tuđinske i nenarodne uprave na hrvatskom nacionalnom biću realan je i danas kao i prije, jer se model odnosa prema hrvatskom biću nije promijenio« (Šimunović, 1994: 44). 
i metodologije konstrukcije utemeljenja pojedinih statističkih regija dovelo do brojnih sučeljavanja stručne i šire javnosti. »Pri agregiranju administrativnih jedinica mora se voditi računa o relevantnim kriterijima poput zemljopisnih, povijesnih, kulturnih, okolišnih i drugih čimbenika. Međutim, iako površinom i brojem stanovnika vrlo mala, $\mathrm{RH}$ je regionalno vrlo raznolika. Pritom nema izrazito jasnih prirodnih ili povijesnih granica između postojećih županija, temeljem kojih bi se jednostavno odredile regionalne cjeline« (Maleković i Jurlin, 2012: 2).

Treba naglasiti da dio nepovjerenja, prije svega županijskih političkih struktura, proizlazi iz pretpostavke da je riječ o ustroju novih političkoadministrativnih, a ne statističkih jedinica. Takvo je stanje dobro okarakterizirao Šantić (2006) nazvavši ga »hrvatski regionalni grč«. Premda je po definiciji riječ o statističkim jedinicama, one se sadržajno vežu uz krajnje pragmatičan cilj, a to je dodjela sredstava iz (strukturnih i kohezijskih) fondova EU-a, čime one postaju regije sui generis ili »statistička razvojna područja« jer dodijeljena investicijska sredstva na bilo kojoj NUTS razini i po statističkim indikatorima dodjele, a posebice po svojim multiplikatorskim učincima imaju razvojnu komponentu promatrane jedinice. Naime razvojna područja (koja su teritorijalno i administrativno definirana) dosad su podrazumijevala upravno i razvojno implementiranje države, to jest njezinu intervenciju osobito kroz subvencioniranje određenih djelatnosti kako bi ta područja dosegnula razvojni priključak s ostalim razvojno više rangiranim područjima države. U novoj situaciji tu ulogu državnog proračuna preuzimaju ponajprije kohezijski fondovi EU-a. Indikatori po kojima se dodjeljuju financijska sredstva ovise o dvije sastavnice: demografskoj i gospodarskoj. Polazište kohezijske politike jest NUTS 2 razina. Kod nas je ona nastala agregiranjem geografski bliskih županija (NUTS 3 jedinica).

Dok Jadranska Hrvatska (jedna od dvije hrvatske statističke regije NUTS 2) ima izvjesnu homogenost (prostorno-geografsku, klimatsku, kulturološ$\mathrm{ku}$, gospodarsku i povijesnu), za drugu, Kontinentalnu Hrvatsku to se ne može reći. Budući da je prag korištenja sredstvima glavnine izvora temeljenog na principima kohezijske politike uvjetovan činjenicom da je BDP po stanovniku za NUTS 2 regiju niži od $75 \%$ prosjeka EU-a u posljednje tri godine, razvidno je da BDP ne definira isključivo njegov apsolutni iznos, već i demografska komponenta, a to je broj stanovnika.

Republika Hrvatska prilikom dugotrajnih pregovora o pristupanju EU-u ponudila je Europskoj komisiji i Eurostatu prijedlog podjele državnog teri- 
torija na NUTS 2 regije triju statističkih cjelina": Sjeverozapadnu Hrvatsku, Panonsku Hrvatsku i Jadransku Hrvatsku. Sjeverozapadna Hrvatska obuhvaćala je šest županija - Zagrebačku, Krapinsko-zagorsku, Varaždinsku, Koprivničko-križevačku i Međimursku te Grad Zagreb, pa bi po popisu stanovništva iz 2011. brojila 1.645 .854 stanovnika ili 38,4\% ukupne državne populacije. Panonsku Hrvatsku u toj trojnoj podjeli činilo bi 8 NUTS 3 jedinica: Karlovačka, Sisačko-moslavačka, Bjelovarsko-bilogorska, Virovitičko-podravska, Požeško-slavonska, Brodsko-posavska, Osječko-baranjska i Vukovarsko-srijemska županija s demografskim obujmom od 1.227.100 stanovnika i udjelom 28,6\% ukupnog stanovništva, dok bi u Jadransku Hrvatsku u sastav ušle Istarska, Primorsko-goranska, Ličko-senjska, Zadarska, Šibensko-kninska, Splitsko-dalmatinska i Dubrovačko-neretvanska županija te bi brojile 1.411 .935 stanovnika ili 33,0\% stanovništva Republike Hrvatske. Dakle vidljivo je da je tom podjelom broj stanovnika pojedinih statističkih NUTS 2 regija bio približno izjednačen. Valja naglasiti da je ta trojna statistička podjela bila ugrađena u Strategiju regionalnog razvoja $\mathrm{Hr}-$

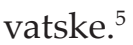

No tom podjelom objelodanile su se bitne razlike u dosegnutom stupnju gospodarskog razvoja. Panonska Hrvatska u usporedbi sa zemljama EU-a (usporedba iz 2003.) dosegnula je njihovu razinu tek od 36\% razine BDP-a po glavi stanovnika, Jadranska Hrvatska 50\%, a Sjeverozapadna Hrvatska $66 \%$. Budući da se u vrijeme intenzivnih pregovora u EU-u nazirala europska gospodarska recesija, a Hrvatska je još donekle bila u uzlaznoj gospodarskoj fazi, prijetila je opasnost da će Sjeverozapadna Hrvatska vrlo brzo dosegnuti 75\% razine BDP-a 27 zemalja EU-a, što bi tu regiju eliminiralo iz raspodjele sredstava iz određenih fondova. $U$ tim okolnostima najlošije bi prošle NUTS 3 regije izvan Grada Zagreba i eventualno Zagrebačke županije, koje po dosegnutoj razini razvijenosti pripadaju skupini nerazvijenih regija, ali zbog prevladavanja razine Grada Zagreba u izračunavanju zajedničke razine BDP-a po glavi stanovnika ne bi mogle konkurentno participirati u dodjeli sredstava specifičnih fondova EU-a. Stoga je pred sam primitak Republike Hrvatske u EU od Europske komisije i Eurostata prihvaćen Vladin prijedlog nove podjele Republike Hrvatske na dvije NUTS regije, čime je realiziran jedan od glavnih preduvjeta za uspješno korištenje strukturnim fondovima i Kohezijskim fondom. Nova podjela počela se pri-

4 Nacionalna klasifikacija prostornih jedinica za statistiku (NKPJS), Narodne novine, 35/2007.

5 Strategija regionalnog razvoja Hrvatske 2011. - 2013., usvojena je na 59. sjednici Vlade RH, 4. lipnja 2010. (Ministarstvo regionalnog razvoja, šumarstva i vodnoga gospodarstva Republike Hrvatske, 2010). 
mjenjivati 1. siječnja 2013. Tim statističkim ustrojem Republika Hrvatska podijeljena je na Jadransku i Kontinentalnu Hrvatsku. Jadranska Hrvatska obuhvaća iste županije kao i prilikom formiranja NUTS 2 jedinica 2007., dok je Kontinentalna Hrvatska definirana spajanjem NUTS 2 jedinica: Sjeverozapadne i Panonske Hrvatske. ${ }^{6}$ Time se još jedanput potvrdila činjenica o daleko izraženijoj homogenosti Jadranske Hrvatske nego Panonske Hrvatske. »Činjenica je da je Jadranska Hrvatska nesumnjivo korektno izdvojena i prihvaćena kao regija NUTS II, čije granice ne treba mijenjati, jer odgovara i 'statističkom' (NUTS) i fizionomskom i funkcionalnom aspektu regionalizacije« (Magaš, 2011: 218).

Ubrzo nakon prihvaćanja dvojne statističke regionalizacije Republike Hrvatske postavljala su se pitanja je li ta regionalizacija izvedena po optimalnim našim kriterijima7 regionalizacije ili su pak kriterije nametnula pregovaračka tijela EU-a. U svakom slučaju, možemo ocijeniti jednu nedosljednost prilikom implementacije demografskih kriterija. Prijedlog Hrvatske da se Grad Zagreb izdvoji kao zasebna NUTS 2 regija odbijen je s obrazloženjem da takvu poziciju glavni grad ne može imati jer ne ispunjava demografski prag od 800.000 stanovnika. Znajući demografske podatke brojnih NUTS 2 regija u ostalim zemljama EU-a, zaključujemo da postoji nemali broj regija tog ranga koje ni približno nemaju toliko stanovnika (primjerice Francuska ima šest NUTS 2 regija s manje od 800.000 stanovnika). Osim toga i prilikom konstruiranja statističkih makroregija Hrvatske nije bilo dosljednosti u tretiranju demografskih kriterija NUTS 3 regija. Od 21 hrvatske županije koja čini Jadransku i Kontinentalnu Hrvatsku tek jedanaest ima više od 150.000 stanovnika, što se smatra minimalnim za ustroj NUTS 3 jedinice.

Nacionalna klasifikacija prostornih jedinica za statistiku 2012. (NKPJS 2012.), Narodne novine, 96/2012.

7 Maleković i Jurlin (2012: 3) obrazlažu prednosti dviju u odnosu na tri (aktualnu podjelu u vrijeme pisanja njihova članka; op. a.): »Sadašnja podjela na tri regije rezultirala bi nepovoljnim financijskim učincima za županije Sjeverozapadne Hrvatske, jer bi zbog dostizanja granice od 75\% BDP-a po stanovniku u odnosu na prosjek EU (mjereno paritetom kupovne moći valuta) ta statistička regija u idućoj financijskoj perspektivi (2014. - 2020.) izgubila status manje razvijenih područja koja potpadaju pod najizdašniji, Cilj 1 Kohezijske politike - konvergencija, i imala bi nižu stopu sufinanciranja projekata iz strukturnih fondova (oko $60 \%$ umjesto prosječnih $75-85 \%$.) Nova podjela na dvije statističke regije omogućit će bolje iskorištenje alociranih sredstava od 450,0 mil. eura do kraja 2013. te 1,1 do 1,5 mlrd. eura svake iduće godine. Pri tom nema sumnje, da će sredstava za dobro pripremljene projekte biti dovoljno, ali ključno je pitanje hoće li se uspjeti pripremiti dovoljan broj kvalitetnih projekata, s dugoročnim bitnim značenjem za razvoj svih hrvatskih područja.« 
Slika 1. Podjela Hrvatske na statističke jedinice NUTS 1, 2 i 3

Figure 1. Division of Croatia into NUTS 1, 2 and 3 statistical units

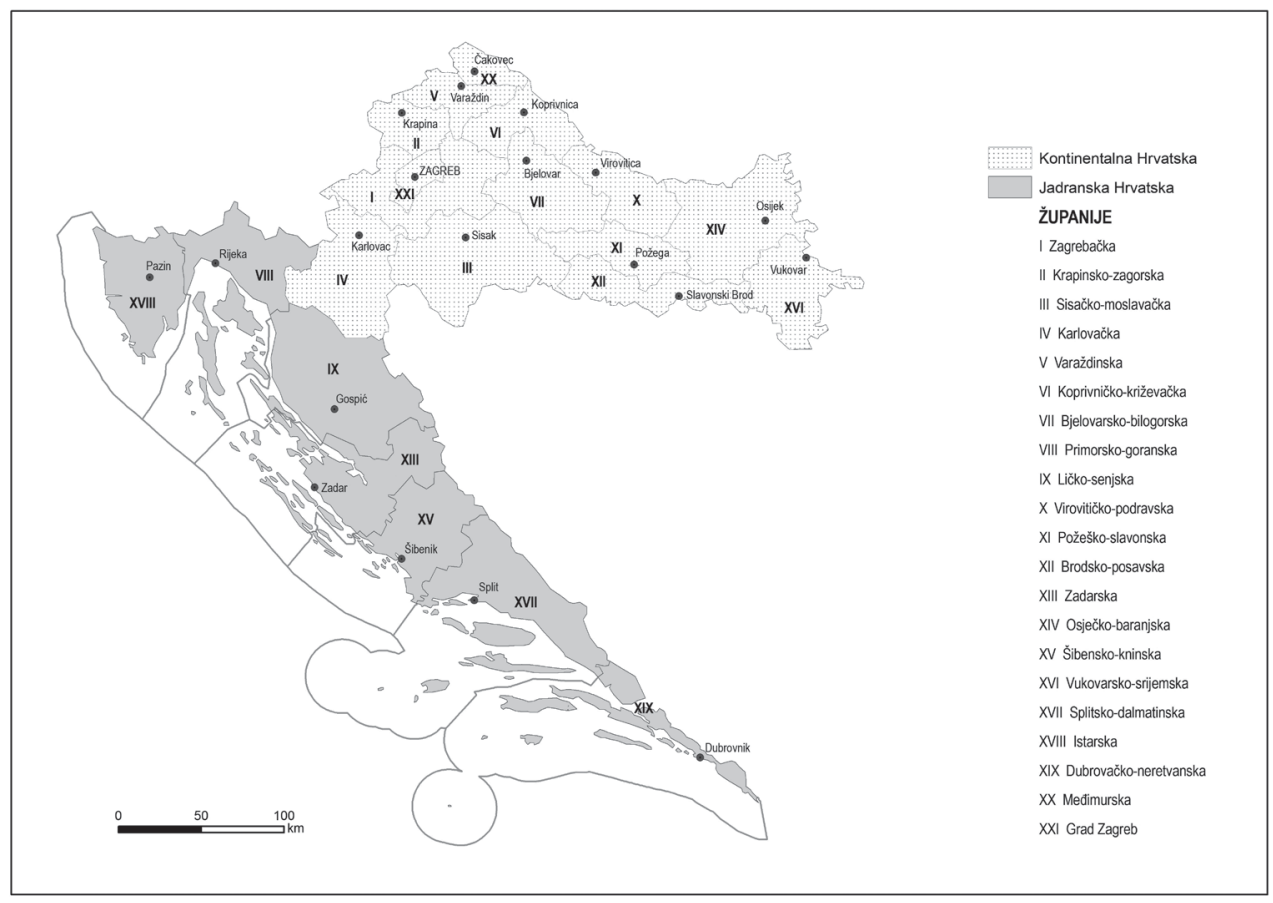

Osim za provedbu kohezijske politike EU-a regionalne statistike imaju veliku važnost i za provedbu politike tržišnog natjecanja, ali i drugih politika u EU-u, prije svega poljoprivredne. Statistički indikatori rangiraju statističke regije EU-a na nacionalnoj i subnacionalnoj razini (ponajprije kriterijem BDP-a po glavi stanovnika) koje su pogodne za primjenu instrumenata ovih politika, sukladno utvrđenim mjerilima zajedničkim za čitavo područje Europske unije. Dvojnom statističkom podjelom sav teritorij Republike Hrvatske može dobiti sredstva EU-a. U protivnome, ako bi se kao posebna regija izdvojio Grad Zagreb, glavni grad i centar hrvatskoga gospodarstva i zapošljavanja, našao bi se izvan koncepta konkurencije dodjele sredstava, ali bi zato ostale NUTS 3 regije Kontinentalne Hrvatske imale daleko niži prosjek BDP-a po glavi stanovnika, koji bi omogućivao veće i dugoročnije prigode za dodjelu sredstava iz pojedinih europskih fondova. U tako nehomogenoj i preglomaznoj Kontinentalnoj regiji posebno se zakinutom smatra bivša Panonska regija, čiji su osnovni indikatori razvijenosti bili znatno ispod razine Grada Zagreba. Pozitivna je strana te razdiobe da sve regije 
mogu aplicirati za sredstva EU-a, međutim prijeti opasnost nemogućnosti vođenja regionalne politike, čiji je osnovni smisao brži razvoj nerazvijenih regija i približavanje razine razvijenosti onoj najrazvijenijih regija. Gotovo je nemoguće osmišljavati zajedničke projekte i zajedničku razvojnu strategiju četrnaest županija koje su po svim značajkama nekompatibilne.

\section{Cilj i metodološka ograničenja}

S obzirom na važnost demografske komponente u NUTS regionalizaciji, osnovni je cilj ovog članka prikazati prevladavajuće recentne demografske procese u statističkim jedinicama NUTS 2 i NUTS 3 razine u Hrvatskoj, fokusirajući se na dinamičniji segment općega kretanja, migracije. Naime migracije u vrlo kratkom roku mogu determinirati opće kretanje stanovništva, dok je prirodno kretanje sporiji proces koji se tek s određenim vremenskim odmakom odražava na promjenu ukupnog broja stanovnika promatrane jedinice.

Analizirat će se rezultati najnovijeg popisa stanovništva (2011.) za NUTS 1, 2 i 3 prema migracijskim obilježjima: odnos broja domorodnog i doseljenog stanovništva, podrijetlo doseljene populacije, razdoblje doseljavanja te migracijski saldo statističkih regija. Preko godišnjih priopćenja DZS-a o migracijama od 2001. do 2013. analizirat će se lokalne, unutaržupanijske i međužupanijske migracije.

Posebni problem u demografskim istraživanjima u Hrvatskoj, o kojem se već puno pisalo, jest metodološka neujednačenost posljednjih triju popisa stanovništva (1991., 2001. i 2011.), zbog čega njihovi rezultati nisu u potpunosti usporedivi. Iako se podaci dvaju posljednjih popisa, 2001. i 2011. temelje na konceptu »uobičajenog mjesta stanovanja«, ni oni nisu u potpunosti usporedivi. U popisu 2001. nije se od ispitanika tražilo očitovanje o namjeri odsutnosti/prisutnosti, a ukupni broj stanovnika uključivao je i osobe odsutne godinu i dulje koje su se u mjesto stalnog stanovanja vraćale sezonski i mjesečno. U popisu 2011. te osobe nisu uključene u ukupni broj stanovnika, ali su se prikupljali podaci o namjeri odsutnosti/prisutnosti.

$\mathrm{Na}$ još veći problem nailazimo kod migracijskih istraživanja jer je vrlo malo podataka o migracijama dostupno iz popisâ, pa je vrlo teško kvantificirati obujam i migracijski smjer na državnoj razini, ali i na razini nižih administrativnih jedinica. U Hrvatskoj podatke o migraciji možemo crpiti iz dva izvora: popisâ stanovništva i godišnjeg izvješća DZS-a o migraciji. Iz popisa stanovništva dostupni su podaci o mjestu stanovanja u vrijeme popisa, mjestu i državi rođenja, prijašnjem naselju stanovanja i godini doselje- 
nja. No popis bilježi podatke samo o posljednjem preseljenju i zanemaruje moguće prijašnje migracije ispitanika.

Godišnje izvješće DZS-a o migracijama temelji se na podacima koje im dostavlja MUP na temelju obveze pojedinaca u vezi s promjenom prebivališta (prijave/odjave). I dok podatke o unutrašnjoj migraciji možemo smatrati relativno pouzdanima, usprkos činjenici da je dio stanovništva formalno prijavio prebivalište $\mathrm{u}$ vikendicama iako tamo stalno ne živi, kod razmatranja na razini županija te nepravilnosti uglavnom ne utječu na ukupnu demografsku sliku. No posebni je problem statističko praćenje vanjskih migracija jer stanovništvo koje se iseljava iz Hrvatske u inozemstvo uglavnom ne odjavljuje prebivalište. Osim toga devedesetih godina 20. stoljeća u Hrvatskoj su prijavljivali prebivalište brojni pretežno izbjegli etnički Hrvati iz $\mathrm{BiH}$ radi dobivanja hrvatskih dokumenata, iako u njoj nikada nisu zaista živjeli. To im je omogućilo odseljenje u treće zemlje.

Godine 2012. promijenjen je Zakon o prebivalištu (Narodne novine, 144/12, 158/13) i uvedena je obveza odjave prebivališta prilikom trajnog preseljenja u drugu državu. ${ }^{8}$ Te zakonodavne promjene utjecale su na naglo statističko "povećanje« broja emigranata iz Hrvatske u BiH i Srbiju, zbog hrvatskih državljana s dvojnim državljanstvom koji se ako ne žive u Hrvatskoj dulje od godinu dana, tretiraju kao emigranti. Uglavnom je riječ o Hrvatima iz BiH koji su bili prijavljeni u Hrvatskoj, ali su otišli u treće zemlje ili se vratili u BiH ili o Srbima rodom iz Hrvatske koji u Hrvatskoj već dulje ne žive. ${ }^{9}$

Usprkos važnosti poznavanja procesa migracija migracijski podaci i dalje su vrlo šturi i većina varijabli bitnih za migracijska istraživanja i dalje je nedostupna. Usporedba publikacija DZS-a o prirodnom kretanju i migracijama sama po sebi govori o ogromnoj razlici u kvaliteti i dostupnosti relevantnih podataka. Možemo ustvrditi da je u starijim popisima stanovništva (prije 2001.) bilo dostupno više podataka o migracijama (sve do razine naselja) koji su bili publicirani, dok danas pristup tim podacima traži dodatnu obradu i financijski trošak korisnika.

\section{SUVREMENA DEMOGRAFSKA SLIKA HRVATSKE}

Demografsko stanje u Hrvatskoj dugoročno obilježavaju totalna stopa fertiliteta, koja je još od kraja šezdesetih godina 20. stoljeća ispod razine neophodne za obnovu stanovništva (below replacement level), negativna prirodna promjena (još od početka devedesetih) i vrlo nepovoljna dobna struktura

Detaljnije u Članku 3. Zakona o prebivalištu.

9 Sada sve osobe s dvojnim državljanstvom mogu biti prijavljene na samo jednoj adresi u jednoj državi, tako da u obje putovnice imaju navedenu istu adresu i zemlju prebivališta. 
stanovništva, koju karakteriziraju porast broja starog stanovništva i smanjenje kontingenta mladih (Wertheimer-Baletić, 2005; Podgorelec i Klempić, 2007). U tim okolnostima migracije su čimbenik koji može značajnije utjecati na ukupne promjene broja stanovnika, njihov razmještaj i demografske strukture.

Tijekom desetljeća demografskih istraživanja u Hrvatskoj veliki naglasak bio je stavljen na iseljavanje $\mathrm{u}$ inozemstvo kao bitni čimbenik promjena ukupnog broja stanovnika. Istovremeno su se odvijale i intenzivne unutarnje migracije koje nisu utjecale na promjenu ukupnog broja stanovnika države, ali su značajno utjecale na geografsku redistribuciju stanovništva unutar Hrvatske te tako i na razlike u demografskim kretanjima između pojedinih regija. One su pridonijele demografskoj polarizaciji Hrvatske, koja se ogledala u demografskoj progresiji gradskih područja i istovremeno regresiji ruralnih područja države. Vitalnost demografskih zbivanja (prirodni prirast i pozitivni migracijski saldo) veže se uz najveće gradove, što stvara dodatni problem asimetričnog prostornog razvoja snaženjem oligocentričkog značenja regionalnih središta (Lajić, 2002: 136).

Unutarnje su migracije tijekom desetljeća doživjele značajne promjene. I dok su šezdesete i sedamdesete godine 20. stoljeća vrhunac migracije sa sela u grad, kada je neto migracijski saldo seoskih naselja iznosio 494.571 (Nejašmić, 1988), osamdesetih se polako mijenjaju obrasci unutarnjih migracija. Značajno se smanjuje obujam migracija sa sela u grad zbog demografske iscrpljenosti rurisa, ali i zbog sve dublje ekonomske krize i smanjenih mogućnosti zapošljavanja u gradovima. U tom razdoblju zbog smanjene imigracije i prirodnog prirasta veliki hrvatski gradovi bilježe usporavanje rasta stanovništva, koje će devedesetih prijeći u populacijsku regresiju (Klempić Bogadi i Podgorelec, 2009; Klempić Bogadi, 2010). Istovremeno jačaju suburbanizacijski procesi u okolici, čija je značajka i dekoncentracija stanovništva iz centralnoga grada u okolicu, pa se tako brojna do tada ruralna naselja počinju socioekonomski transformirati (Klempić Bogadi, 2010).

Ratna zbivanja na prostoru bivše Jugoslavije devedesetih pokrenula su masovne migracije te su prisilne migracije - prognanici i izbjeglice - značajno utjecale na demografske trendove općenito, ali i na redistribuciju stanovništva unutar Hrvatske. Istovremeno su se odvijali preseljavanje unutar Hrvatske, iseljavanje iz Hrvatske prema državama bivše SFRJ (uglavnom BiH i Srbiji) i inozemstvu, ali i useljavanje uglavnom etničkih Hrvata iz Bosne i Hercegovine i Srbije. Živić (2014: 312-313) procjenjuje demografsku bilancu prisilnih (ratnih) migracija u devedesetima na 1.469 .316 migranata, od kojih se nešto manje od trećine odnosilo na izbjeglice iz drugih država u 
Hrvatsku, dok su većinu činili prisilni migranti (»unutarnji« i »vanjski«) $\mathrm{s}$ prijeratnim prebivalištem na području Hrvatske. Osim rata i teška ekonomska situacija u Hrvatskoj bila je potisni čimbenik za intenziviranje vanjskih migracija, koje se nastavilo i u prvom desetljeću 21. stoljeća, a s novom krizom od 2008. taj oblik migracija jača.

U prvom desetljeću 21. stoljeća na razini cjelokupne populacije Hrvatske, ali i većine županija nastavljaju se nepovoljni demografski procesi iz prethodnog desetljeća, depopulacija i starenje, koji sve više postaju ograničavajući čimbenici u društvenom i gospodarskom razvoju. I dok je od 1948. do 1991. usprkos negativnome migracijskom saldu prirodno kretanje bilo dominantna odrednica ukupnoga kretanja stanovništva, slijedi promjena tog trenda (Wertheimer-Baletić, 2005). Od početka devedesetih zbog ratnih zbivanja i ekonomskih poteškoća u državi, jačaju vanjske migracije, što u kombinaciji s negativnom prirodnom promjenom pridonosi depopulaciji stanovništva Hrvatske.

Od 2001. do 2011. Hrvatska je izgubila 152.571 stanovnika ili 3,4\%. Iako zbog metodoloških razlika posljednjih dvaju popisa podaci nisu posve usporedivi i s velikom vjerojatnošću možemo tvrditi da je ukupno smanjenje stanovništva nešto manje, te nedosljednosti ne utječu na predznak demografskih trendova, koji je svakako negativan. Mrđen (2014) nekritički poistovjećuje ukupni broj stanovnika popisa 2011. s tzv. kontingentom stanovništva u zemlji 2001., zanemarujući pritom činjenicu da su se u popisu 2011. prikupljali podaci koristeći se i varijablom namjera odsutnosti/prisutnosti, čime je zasigurno opet $\mathrm{u}$ ukupni broj stanovnika ušao i dio onih koji žive u inozemstvu. Za razdoblje 2001. - 2011. navodi ukupni porast broja stanovnika Hrvatske od 73.580 i pozitivni migracijski saldo od 168.943 stanovnika, što je statistički nemoguće. Prema podacima popisa 2011. o razdoblju doseljavanja stanovništva, proizlazi da su se od 2001. do 2011. u Hrvatsku doselila 122.443 stanovnika, a u istom razdoblju zabilježeno je negativno prirodno kretanje (-95.047), iz čega zaključujemo i da se nitko nije iselio iz Hrvatske ne može biti ovoliki porast stanovništva ili migracijski saldo.

Ako u odnos stavljamo izravno podatke o ukupnom broju stanovnika $\mathrm{RH}$, metodološke razlike na razini županija ne utječu na predznake demografskih promjena. Tako su u ovom razdoblju i obje NUTS 2 regije depopulirale, s tim da je Kontinentalna Hrvatska zabilježila veću stopu depopulacije $(-4,6 \%)$ stanovništva. Na području te statističke regije samo su Grad Zagreb i Zagrebačka županija, koji socioekonomski čine Zagrebačku gradsku regiju i žarište su ekonomske moći u državi, zabilježili demografsku progresiju, pa je ona u Zagrebu iznosila 1,4\%, dok je Zagrebačka županija imala demo- 
grafski rast od 2,6\%. Godine 2011. Grad Zagreb imao je daleko najveći BDP po stanovniku u Hrvatskoj (BDP Hrvatske $10.325 €$ ), čak $18.503 €$, i najnižu stopu nezaposlenosti $(8,2 \%)$, dok je u Zagrebačkoj županiji BDP bio znatno manji, $7786 €^{10}$, međutim te dvije županije praktično čine jedan ekonomski i demografski organizam. ${ }^{11}$ Porast broja stanovnika u okolici Zagreba, koju uglavnom čine naselja Zagrebačke županije, rezultat je suburbanizacijskih procesa, pa u naseljima okolice pod utjecajem doseljavanja jača dinamika prirodnoga kretanja (Klempić Bogadi, 2010). Preostalih je dvanaest županija Kontinentalne Hrvatske depopuliralo, čime je potvrđen očekivani nastavak negativnih demografskih tendencija iz prethodnog desetljeća.

Najnegativnije trendove demografskoga kretanja pokazuju dvije pogranične županije Vukovarsko-srijemska i Brodsko-posavska, koje su od 2001. do 2011. izgubile više od deset posto stanovništva (tablica 1). U Vukovarsko-srijemskoj županiji nastavlja se demografski pad iz prethodnoga međupopisnoga razdoblja (1991. - 2001. $=-11,4 \%)^{12}$, tada uzrokovan brojnim ljudskim žrtvama i prisilnim iseljavanjem zbog ratnih razaranja i okupacije. Očito se dio raseljenog stanovništva (Hrvata, ali i Srba) nije vratio ovamo ni nakon mirne reintegracije te infrastrukturne i stambene obnove porušenih objekata koju je financirala država. Brojni su razlozi za takvu situaciju. Dugotrajnost prognaništva i izbjeglištva učinila je da se dio njih, posebice mlađih stanovnika prilagodio životu u novoj sredini i ne želi se vratiti. Za dio stanovništva razlozi su emocionalne i psihološke prirode, zbog čega nisu spremni ponovno ovdje živjeti. Razloge možemo pronaći i u propasti industrije i nestanku brojnih radnih mjesta pa se tako Vukovar, koji je nekada bio najjači ekonomski centar regije, nije uspio gospodarski oporaviti, dok su istovremeno Vinkovci zbog brojnih problema tranzicijskoga gospodarstva također ekonomski slabjeli. To potvrđuju i podaci o BDP-u po stanovniku za 2011., kada je on iznosio $6217 €$, čime je ta županija bila na predzadnjemu

10 Podaci o BDP-u za 2011. preuzeti su iz Priopćenja 12.1.2. »Bruto domaći proizvod za Republiku Hrvatsku, NKPJS - 2. razina i županije u 2011.«, DZS, Zagreb, veljača 2014., www. dzs.hr. Podaci o broju nezaposlenih preuzeti su iz Analitičkog biltena (2011), Hrvatski zavod za zapošljavanje, 13 (4).

11 Sić (2003) na temelju triju skupina pokazatelja, demografskog razvoja, ekonomske razvijenosti i stupnja opskrbljenosti stanovništva, izdvaja Grad Zagreb i Zagrebačku županiju kao izrazitu regiju jezgre, Split, Rijeka i Osijek formiraju regije sekundarnih jezgri, a nasuprot njima nalaze se prostrana nerazvijena i periferna područja. Prostor južno od Karlovca i Siska te sjeverno od Zadra i Šibenika najveće je kompaktno nerazvijeno područje u Hrvatskoj.

12 Ako se usporedi za 1991. i 2001. samo broj stanovnika u zemlji, onda je u tom razdoblju Vukovarsko-srijemska županija izgubila 13,3\% stanovništva, Karlovačka 20,5\%, Ličkosenjska 33,7\%, a Zadarska 19,4\%. 
mjestu u RH. Niži BDP ima samo Brodsko-posavska županija, $5882 €$ po stanovniku, koja ima samo nešto slabiju razinu depopulacije, $-10,3 \%$. Te su dvije županije i među najlošijima s obzirom na razinu zaposlenosti. Stopa nezaposlenosti u Brodsko-posavskoj iznosi 31,9\%, a u Vukovarsko-srijemskoj $29,6 \%$ te su očit primjer povezanosti ekonomskog i demografskog razvoja, pa pokazuju negativne trendove na obje razine.

Demografska situacija gotovo je jednako loša i u Bjelovarsko-bilogorskoj, Virovitičko-podravskoj, Požeško-slavonskoj i Karlovačkoj županiji, koje su u deset godina izgubile između devet i deset posto stanovništva. Intenzitet njihove depopulacije samo je nastavak nepovoljnih procesa započetih još osamdesetih, tako da su te četiri županije već 1991. zabilježile ukupno smanjenje broja stanovnika, iako je realno popis 1991. obuhvatio veći kontingent »inozemaca« nego prijašnja dva popisa (1971. i 1981. $)^{13}$. Čak ni ta metodološka nepravilnost nije uspjela neutralizirati ni sakriti snagu depopulacije. $U$ devedesetima se intenzitet depopulacije u tim županijama pojačao, što je posebno došlo do izražaja u ratom zahvaćenim područjima, gdje je rat još dodatno produbio i ubrzao ionako nepovoljne demografske procese. Karlovačka je županija od 1991. do 2001. izgubila čak 23,2\% stanovnika. Turk (2008) osim rata navodi nekoliko čimbenika koji su tu županiju već prije demografski destabilizirali: prometna izoliranost, manjak ulaganja u ekonomski razvoj te naslijeđena nepovoljna demografska kretanja i strukture. Jedina županija u Kontinentalnoj Hrvatskoj koja je u međupopisnom razdoblju 1991. - 2001. zabilježila još jaču depopulaciju jest Sisačkomoslavačka (26,2\%). Tijekom Domovinskog rata u prisilnim migracijama sudjelovala je polovina stanovništva te županije popisanog 1991. kao »stanovništvo u zemlji «, od kojih se u pet godina od oslobađanja okupiranog prostora u nju nije vratila ni polovina (52.922) prisilnih migranata (Mišetić, 2002). Istovremeno se veliki broj izbjeglica iz $\mathrm{BiH}$ (uglavnom etničkih Hrvata koji su imali pravo na hrvatsko državljanstvo) trajno naselio u Hrvatskoj, i to uglavnom na područjima od posebne države skrbi. Sredinom 1997. po broju i udjelu izbjeglica useljenika ističu se Sisačko-moslavačka (33,8\%), Karlovačka (20,3\%), Bjelovarsko-bilogorska (11,5\%) i Brodsko-posavska županija (11,4\%) (Živić, 1999: 784). No ni taj useljenički kontingent nije uspio

13 Godine 1991. popis je obuhvatio 285.216 stanovnika u inozemstvu, što je porast od 35,6\% u odnosu na 1981. Budući da se osamdesetih nije pojačala vanjska migracija, razlozi povećanja očito su metodološke prirode. Nejašmić (1994: 142) kao razlog navodi bolji popisni obuhvat, točnije da su u popisu 1991. bolje obuhvaćeni iseljenici u prekomorskim zemljama, ali i činjenicu da je »...nakon demokratskih promjena dio je iseljenika želio 'ući' u popis stanovništva, pokazujući i time svoje domoljublje (ili je njihova rodbina koja je za njih davala podatke tako osjećala).« 
kompenzirati dotadašnje migracijske gubitke ni poboljšati demografsku sliku na ovim prostorima.

Unutar Jadranske Hrvatske depopulacijski procesi znatno su slabiji, pa je pad stanovništva u razdoblju 2001. - 2011. iznosio svega 1,1\%. Čak je i Ličko-senjska županija, koja je devedesetih predvodila depopulaciju jer je tada izgubila trećinu stanovništva (37\%), zabilježila u posljednjemu međupopisnom razdoblju depopulaciju od $-5,1 \%$. U toj NUTS 2 regiji pet je županija depopuliralo, dok su dvije zabilježile demografski porast. Najveću demografsku progresiju na razini Jadranske Hrvatske, ali i Hrvatske u cjelini imala je Zadarska županija (4,9\%), što djelomično možemo povezati s činjenicom da je Zadar jedini veći obalni grad koji je u tom razdoblju imao porast broja stanovnika. Godine 2001. imao je 69.556 stanovnika (70.494 prema metodologiji iz 1991.), a 2011. g. 71.471. I na tom primjeru još se jednom pokazalo da je ekonomski razvoj generator pozitivnih demografskih trendova. Tako je Zadar kvalitetno iskoristio novoizgrađenu autocestu, širenje sveučilišta i sl. te ojačao regionalne funkcije, što je pozitivno utjecalo na njegovu ekonomsku snagu i demografsku vitalnost, a samim time i migracijsku atraktivnost.

Zanimljivo je da je ta županija u devedesetima zabilježila pad broja stanovnika od čak $24,6 \%$ i time bila među tadašnjim depopulacijskim rekorderima. Što se dogodilo u deset godina? Očito je devedesetih došlo do »neregularnih« kretanja, pa je iz usporedbe međupopisne promjene i prirodnoga kretanja jasno da su migracije bile ključni čimbenik. Masovni odlasci, u početku Hrvata iz okupiranih područja, a tijekom i nakon vojno-redarstvene akcije Oluja Srba, demografski su destabilizirali tu županiju. Iz ukupnog broja stanovnika 2011. i udjela Srba u etničkoj slici Hrvatske očito je da se samo manji dio njih vratio u Hrvatsku. Iako se i u Zadarskoj županiji vratio samo manji dio iseljenoga srpskog stanovništva, to se uslijed nepovoljnoga prirodnoga kretanja odrazilo na ukupni broj stanovnika županije. Iako nemamo točne podatke o povratku, možemo ih iščitati posredno iz etničke strukture Zadarske županije: 2001. udio Srba iznosio je 3,53\%, a 2011. g. 4,81\% (2001. g. 5716, a 2011. g. 8184).

Od ukupno 314.689 izbjeglica u Srbiji za koje je bilo poznato prijeratno prebivalište, sredinom 1996. najviše ih je bilo podrijetlom iz Sisačko-moslavačke županije (70.648 ili 22,5\%), Šibensko-kninske (49.410 ili 15,7\%), Zadarske (41.676 ili 13,2\%), Karlovačke (32.205 ili 10,2\%), Ličko-senjske (27.317 ili 8,7\%), Osječko-baranjske (15.905 ili 5,1\%) i Požeško-slavonske (12.108 ili 3,8\%) (Živić, 2014: 309). U drugoj polovini devedesetih njihov je povratak 
bio usporen, ${ }^{14}$ pa se u većem broju vraćaju početkom 21 . stoljeća, kada uspijevaju regulirati vlasnička prava nad nekretninama, mirovine i sl. No uglavnom je riječ o starijoj povratničkoj populaciji, koja može pozitivno utjecati na ukupni broj stanovnika i neto saldo, ali na sve drugo njezin je utjecaj dugoročno negativan - pojačava starenje, ekonomsku ovisnost, mortalitet i sl. ${ }^{15}$ Istraživanje koje su proveli Mesić i Bagić 2010. pokazalo je da tek svaki treći registrirani manjinski povratnik $(33,2 \%)$ zaista živi u Hrvatskoj, dok ih $38,7 \%$ živi izvan Hrvatske (od toga 70\% u Srbiji), 14,8\% njih je preminulo, a za 13,3\% nema pouzdanih informacija (Mesić i Bagić, 2011: 189). ${ }^{16}$

Tablica 1. Opće kretanje broja stanovnika NUTS 1, NUTS 2 i NUTS 3 regija Hrvatske u međupopisnom razdoblju 2001. - 2011.

Table 1. Overall population trends of Croatian NUTS 1, NUTS 2 and NUTS 3 regions in the 2001-2011 intercensus period

\begin{tabular}{|c|c|c|c|}
\hline & \multicolumn{2}{|c|}{ Broj stanovnika } & \multirow{2}{*}{$\begin{array}{c}\text { Indeks } \\
\text { promjene } \\
2011 . / 2001 .\end{array}$} \\
\hline & 2001. & 2011. & \\
\hline Zagrebačka & 309.696 & 317.606 & 102,6 \\
\hline Krapinsko-zagorska & 142.432 & 132.892 & 93,3 \\
\hline Sisačko-moslavačka & 185.387 & 172.439 & 93,0 \\
\hline Karlovačka & 141.787 & 128.899 & 90,9 \\
\hline Varaždinska & 184.769 & 175.951 & 95,2 \\
\hline Koprivničko-križevačka & 124.467 & 115.584 & 92,9 \\
\hline Bjelovarsko-bilogorska & 133.084 & 119.764 & 90,0 \\
\hline Virovitičko-podravska & 93.389 & 84.836 & 90,8 \\
\hline Požeško-slavonska & 85.831 & 78.034 & 90,9 \\
\hline Brodsko-posavska & 176.765 & 158.575 & 89,7 \\
\hline Osječko-baranjska & 330.506 & 305.032 & 92,3 \\
\hline
\end{tabular}

14 Iako je i do tada bilo pojedinačnih povrataka Srba u Hrvatsku, od lipnja 1998., kada je donesen Program povratka i zbrinjavanja prognanika, izbjeglica i raseljenih osoba ( $\mathrm{Na}$ rodne novine, 92/98), slijedi organizirani manjinski povratak. Zivić (2014) navodi podatke UNHCR-a prema kojima se od 1998. do kraja 2011. iz BiH, Srbije i Crne Gore u Hrvatsku vratilo 94.185 izbjeglica.

15 Godine 2010. 30\% povratnika je bilo starije od 65 godina, 38\% od 35 do 64 godina, a 31\% bilo je mladih do 34 godine (Mesić i Bagić, 2011: 86).

16 Istraživanje istih autora provedeno 2006. pokazalo je da je tada 38,3\% manjinskih povratnika zaista živjelo u Hrvatskoj, 35,1\% izvan Hrvatske (od toga 82,3\% u Srbiji), 11,2\% u međuvremenu je preminulo, a za 15,4\% nije bilo pouzdanih informacija (Mesić i Bagić, 2011: 189). 


\begin{tabular}{|c|c|c|c|}
\hline & \multicolumn{2}{|c|}{ Broj stanovnika } & \multirow{2}{*}{$\begin{array}{c}\text { Indeks } \\
\text { promjene } \\
2011 . / 2001 .\end{array}$} \\
\hline & 2001. & 2011. & \\
\hline Vukovarsko-srijemska & 204.768 & 179.521 & 87,7 \\
\hline Međimurska & 118.426 & 113.804 & 96,1 \\
\hline Grad Zagreb & 779.145 & 790.017 & 101,4 \\
\hline $\begin{array}{r}\text { Kontinentalna } \\
\text { Hrvatska }\end{array}$ & 3.010 .452 & 2.872 .954 & 95,4 \\
\hline Primorsko-goranska & 305.505 & 296.195 & 97,0 \\
\hline Ličko-senjska & 53.677 & 50.927 & 94,9 \\
\hline Zadarska & 162.045 & 170.017 & 104,9 \\
\hline Šibensko-kninska & 112.891 & 109.375 & 96,9 \\
\hline Splitsko-dalmatinska & 463.676 & 454.798 & 98,1 \\
\hline Istarska & 206.344 & 208.055 & 100,8 \\
\hline $\begin{array}{l}\text { Dubrovačko- } \\
\text { neretvanska }\end{array}$ & 122.870 & 122.568 & 99,7 \\
\hline Jadranska Hrvatska & 1.427 .008 & 1.411 .935 & 98,9 \\
\hline Hrvatska & 4.437 .460 & 4.284 .889 & 96,6 \\
\hline
\end{tabular}

Izvori: Popis stanovništva, kućanstava i stanova 2001., Državni zavod za statistiku, Zagreb, wwww.dzs.hr; Popis stanovništva, kućanstva i stanova 2011., Državni zavod za statistiku, Zagreb, www.dzs.hr

U posljednjemu međupopisnom razdoblju i na razini NUTS 2 i NUTS 3 regija jasno je da su u Hrvatskoj prisutni vrlo nepovoljni bioreproduktivni procesi (tablica 2). I Kontinentalna i Jadranska Hrvatska bilježe prirodnu depopulaciju, koja je ipak veća u Kontinentalnoj, -2,6\%o, kao rezultat značajno više stope smrtnosti (12,3\%o). Premda Jadranska Hrvatska ima nižu stopu rodnosti, 9,4\%o, niža je stopa i smrtnosti, 10,8\%o, pa je prirodni pad nešto slabiji, $-1,4 \%$. 
Tablica 2. Prirodno kretanje stanovništva NUTS 1, NUTS 2 i NUTS 3 regija Hrvatske između 2001. i 2010.

Table 2. Natural change of Croatian NUTS 1, NUTS 2 and NUTS 3 regions, 2001-2010

\begin{tabular}{|c|c|c|c|c|c|c|}
\hline & Živorođeni & Umrli & $\begin{array}{l}\text { Prirodna } \\
\text { promjena }\end{array}$ & $\mathbf{n}$ & m & pp \\
\hline Zagrebačka & 31.543 & 34.774 & -3231 & 10,1 & 11,1 & $-1,0$ \\
\hline Krapinsko-zagorska & 12.433 & 19.846 & -7413 & 9,0 & 14,4 & $-5,4$ \\
\hline Sisačko-moslavačka & 15.619 & 25.934 & -10.315 & 8,7 & 14,5 & $-5,8$ \\
\hline Karlovačka & 11.067 & 20.588 & -9521 & 8,2 & 15,2 & $-7,0$ \\
\hline Varaždinska & 17.445 & 22.900 & -5455 & 9,7 & 12,7 & $-3,0$ \\
\hline $\begin{array}{l}\text { Koprivničko- } \\
\text { križevačka }\end{array}$ & 11.689 & 17.126 & -5437 & 9,7 & 14,3 & $-4,5$ \\
\hline $\begin{array}{l}\text { Bjelovarsko- } \\
\text { bilogorska }\end{array}$ & 11.868 & 18.549 & -6681 & 9,4 & 14,7 & $-5,3$ \\
\hline $\begin{array}{l}\text { Virovitičko- } \\
\text { podravska }\end{array}$ & 8584 & 12.451 & -3867 & 9,6 & 14,0 & $-4,3$ \\
\hline Požeško-slavonska & 8260 & 10.395 & -2135 & 10,1 & 12,7 & $-2,6$ \\
\hline Brodsko-posavska & 17.092 & 20.222 & -3130 & 10,2 & 12,1 & $-1,9$ \\
\hline Osječko-baranjska & 29.525 & 39.312 & -9787 & 9,3 & 12,4 & $-3,1$ \\
\hline $\begin{array}{l}\text { Vukovarsko- } \\
\text { srijemska }\end{array}$ & 19.601 & 22.707 & -3106 & 10,2 & 11,8 & $-1,6$ \\
\hline Međimurska & 12.579 & 12.597 & -18 & 10,8 & 10,8 & 0,0 \\
\hline Grad Zagreb & 77.303 & 83.013 & -5710 & 9,9 & 10,6 & $-0,7$ \\
\hline $\begin{array}{r}\text { Kontinentalna } \\
\text { Hrvatska }\end{array}$ & 284.608 & 360.414 & -75.806 & 9,7 & 12,3 & $-2,6$ \\
\hline Primorsko-goranska & 24.049 & 34.287 & -10.238 & 8,0 & 11,4 & $-3,4$ \\
\hline Ličko-senjska & 4178 & 8486 & -4308 & 8,0 & 16,2 & $-8,2$ \\
\hline Zadarska & 16.764 & 16.939 & -175 & 10,1 & 10,2 & $-0,1$ \\
\hline Šibensko-kninska & 9524 & 14.432 & -4908 & 8,6 & 13,0 & $-4,4$ \\
\hline Splitsko-dalmatinska & 48.668 & 44.693 & 3975 & 10,6 & 9,7 & 0,9 \\
\hline Istarska & 17.779 & 21.929 & -4150 & 8,6 & 10,6 & $-2,0$ \\
\hline $\begin{array}{l}\text { Dubrovačko- } \\
\text { neretvanska }\end{array}$ & 13.031 & 12.468 & 563 & 10,6 & 10,2 & 0,5 \\
\hline Jadranska Hrvatska & 133.993 & 153.234 & -19.241 & 9,4 & 10,8 & $-1,4$ \\
\hline Hrvatska & 418.601 & 513.648 & -95.047 & 9,6 & 11,8 & $-2,2$ \\
\hline
\end{tabular}

Izvori: Podaci vitalne statistike RH, tablogrami, 2001.-2010., Državni zavod za statistiku, Zagreb. 
Čak devetnaest županija bilježi veći broj umrlih od živorođenih, a samo dvije, Splitsko-dalmatinska $(0,9 \%$ o) i Dubrovačko-neretvanska $(0,5 \%$ o), još uvijek imaju prirodni prirast stanovništva. Te dvije županije u Jadranskoj Hrvatskoj ujedno imaju i najvišu stopu nataliteta u RH, 10,6\%o, dok je Splitsko-dalmatinska jedina županija sa stopom mortaliteta ispod 10\%o. No njihov pozitivni rezultat djelomično je nastao zbog fiktivnog prijavljivanja Hrvata iz BiH koji imaju dvojno državljanstvo, posebice u pograničnim područjima Hrvatske. ${ }^{17}$ No ako analiziramo prirodno kretanje za posljednje tri godine (2011., 2012. i 2013.), dolazimo do poražavajućih podataka da su i te dvije županije zbog sve manjeg broja rođenih zabilježile prirodno smanjenje. U Splitsko-dalmatinskoj županiji u te tri godine bilo je 279 više umrlih nego živorođenih, a u Dubrovačko-neretvanskoj $121 .{ }^{18}$ Godine 2013. nijedna županija u Hrvatskoj nema prirodni prirast stanovništva!

Najnepovoljnija je bioreproduktivna situacija u Ličko-senjskoj (pp = $-8,2 \%$ o) i Karlovačkoj županiji ( pp $=-7 \%$ ). Budući da je razina nataliteta u svim županijama niska, otprilike slična, ključni je čimbenik mortalitet. Očekivano, te dvije županije imaju znatno višu stopu mortaliteta od ostalih županija (Ličko-senjska 16,2\%o, Karlovačka 15,2\%o), ali i u prosjeku najviše starog stanovništva. U Ličko-senjskoj županiji prosječna je starost stanovništva čak 45,3 i svaki četvrti stanovnik prema popisu 2011. ima 65 i više godina $(24,7 \%)$. U Karlovačkoj županiji situacija je samo malo povoljnija, tamo je $21,1 \%$ stanovništva staro 65 i više godina i prosječna je starost 44 godine. Te dvije županije ujedno imaju i najniže stope nataliteta, Ličko-senjska svega 8\%o, a Karlovačka 8,2\%o. Zanimljivo, istu razinu nataliteta bilježi i Primorsko-goranska županija ( $8 \%$ o), međutim stopa mortaliteta ipak je znatno niža $(11,4 \%)$ nego u te dvije županije.

\footnotetext{
Ako se spustimo na razinu gradova/općina, proizlazi da u Dubrovačko-neretvanskoj županiji prirodni prirast bilježe općine/gradovi Metković, Ploče, Župa Dubrovačka, Konavle i Opuzen. U Splitsko-dalmatinskoj i Gradu Splitu, ali i brojnim prigradskim administrativnim jedinicama, Kaštela, Solin, Trogir, Podstrana i Dugi Rat imaju pozitivno prirodno kretanje, dijelom zbog velikog doseljavanja devedesetih, uglavnom mladog stanovništva u najreproduktivnijoj dobi.

18 Prirodna promjena u Splitsko-dalmatinskoj županiji 2011. bila je -77, 2012. g. 75, a 2013. g. -277; u Dubrovačko neretvanskoj 2011. g. -12, 2012. g. -47, a 2013. g. -62 (Prirodno kretanje stanovništva Republike Hrvatske u 2013., Priopćenje 7.1.1., Državni zavod za statistiku, Zagreb, 2014.).
} 
Slika 2. Prirodno kretanje stanovništva NUTS 3 regija Hrvatske između 2001. i 2010.

Figure 2. Natural change of Croatian NUTS 3, 2001-2010

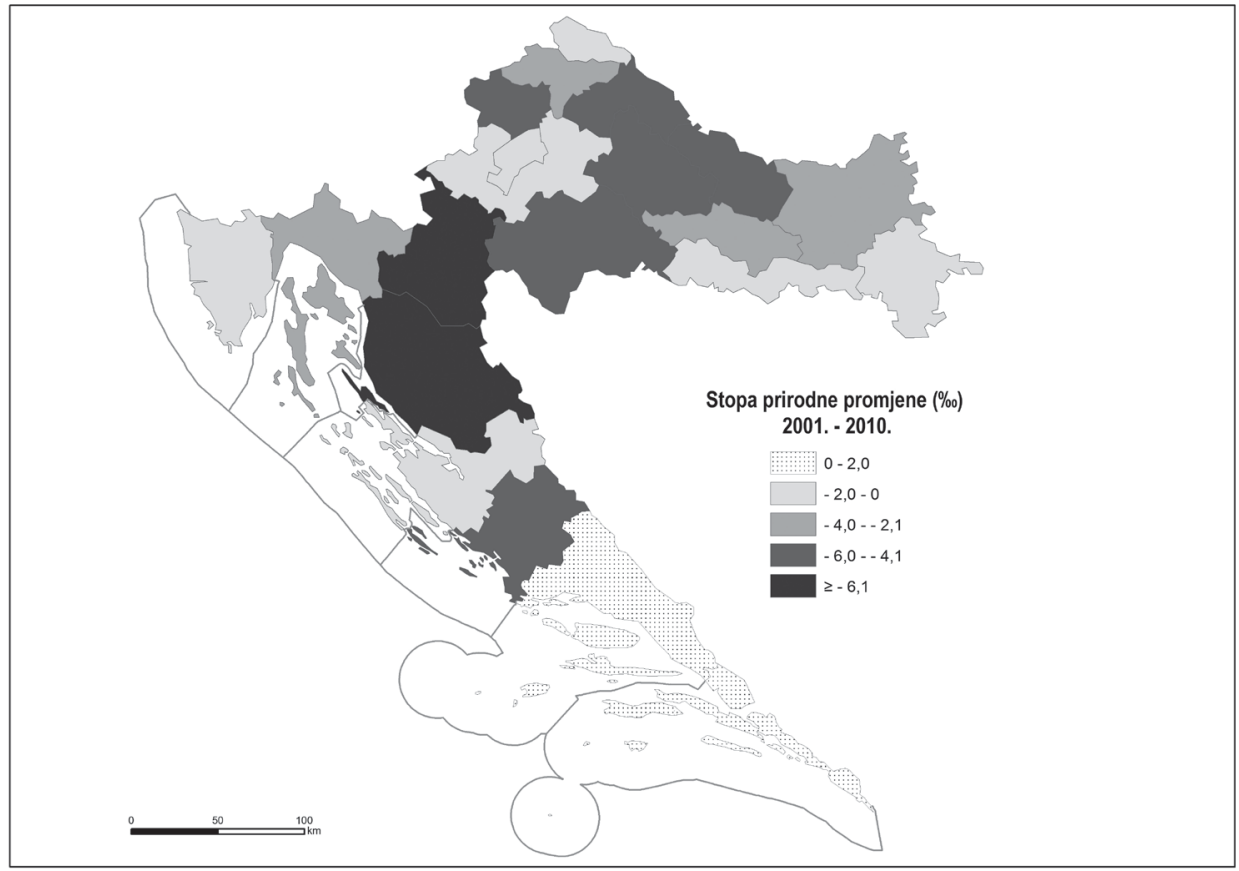

MIGRACIJSKI SALDO 2001. - 2011.

Bez obzira na sve veću važnost migracija za države, u posljednjih deset godina u Hrvatskoj nije došlo do značajnijeg pomaka u kvaliteti migracijskih podataka. Za razliku od njih podatke o prirodnom kretanju možemo smatrati poprilično pouzdanima i kvalitetnima. Do sada se pokazalo da je u RH ipak najpouzdanija vitalnostatistička metoda, tj. da se migracijski saldo računa iz razlike međupopisne promjene i prirodnoga kretanja. Zbog metodoloških nedosljednosti posljednjih dvaju popisa ta će nam metoda poslužiti samo da ilustrativno dobijemo sliku o migracijskom saldu.

Na takav način izračunat migracijski saldo pokazuje da je Hrvatska kroz vanjsku migraciju od 2001. do 2011. izgubila 57.524 stanovnika. Istovremeno, podaci o vanjskoj migraciji iz Priopćenja o migracijama (Državnog zavoda za statistiku) za većinu godina promatranog razdoblja navode po- 
zitivnu migracijsku bilancu Hrvatske, što ne odgovara demografskoj stvarnosti. Prema tim podacima, u Hrvatsku su se u promatranom razdoblju iz inozemstva doselile 153.442 osobe, a odselilo ih se 82.595 , što bi u konačnici rezultiralo pozitivnim migracijskim saldom od 70.847 stanovnika. Ti potpuno različiti podaci, ne samo brojčano nego i u smislu predznaka, govore $\mathrm{u}$ prilog nevjerodostojnosti podataka temeljenih na MUP-ovoj evidenciji vanjske migracije.

U Kontinentalnoj Hrvatskoj situacija je još nepovoljnija, pa je kroz migracije u posljednjemu međupopisnom razdoblju izgubila 61.692 stanovnika i imala migracijsku stopu $-2 \%$. Unutar te statističke jedinice jedino su Grad Zagreb i Zagrebačka županija imali pozitivni migracijski saldo. Za razliku od te statističke regije Jadranska Hrvatska zabilježila je 4168 više doseljenih nego odseljenih te stopu migracije $0,3 \%$. Na tom području većina županija bilježi pozitivni migracijski saldo - Primorsko-goranska, Ličko-senjska, Zadarska, Šibensko-kninska i Istarska. Među tim županijama potrebno je izdvojiti Ličko-senjsku, čija je pozitivna migracijska bilanca očito rezultat povratka, možda stvarnoga, a možda samo fiktivnoga dijela prijeratnog stanovništva. Jer da je ta županija zaista postala atraktivna imigrantima, doseljavalo bi se mlađe reproduktivno stanovništvo, što bi se odrazilo na prirodno kretanje i dobnu strukturu. Slična je situacija i u Šibensko-kninskoj županiji. Istraživanje Mesića i Bagića provedeno 2010. pokazuje da je u Dalmaciji najmanji udio stvarnih manjinskih povratnika. U toj regiji na jednoga trajnoga dolazi 1,7 formalnih povratnika (Mesić i Bagić, 2011: 78).

Ako stavimo $u$ odnos prirodnu promjenu i migracijski saldo, županije možemo podijeliti u tri grupe (tablica 3). Prvu i najbrojniju grupu čini dvanaest županija koje karakteriziraju negativno prirodno i mehaničko kretanje; zanimljivo je da se sve one nalaze u Kontinentalnoj Hrvatskoj. Ipak, i unutar te grupe razlikujemo dvije podgrupe. Prvu čine županije u kojima je mehaničko kretanje dominantni čimbenik depopulacije: Vukovarskosrijemska, Brodsko-posavska, Požeško-slavonska, Virovitičko-podravska, Osječko-baranjska i Međimurska. Drugu podgrupu čine Krapinsko-zagorska, Sisačko-moslavačka, Karlovačka, Varaždinska, Koprivničko-križevačka i Bjelovarsko-bilogorska županija, u kojima je u ukupnoj depopulaciji još uvijek jača komponenta negativno prirodno kretanje.

Drugu grupu, u kojoj se nalazi sedam županija, određuje negativna prirodna promjena, ali pozitivni migracijski saldo. U Kontinentalnoj Hrvatskoj to su Grad Zagreb i Zagrebačka županija, a u Jadranskoj Primorsko-goranska, Ličko-senjska, Zadarska, Šibensko-kninska i Istarska. I dok u dvije županije Kontinentalne Hrvatske te Istarske i Zadarske to rezultira ukupnim 
rastom stanovništva jer je pozitivni migracijski saldo ključan, u ostalim je županijama prirodni pad toliko jak da ga pozitivni migracijski saldo ne uspijeva nadoknaditi.

U trećoj su grupi samo dvije županije - Splitsko-dalmatinska i Dubrovačko-neretvanska, koje imaju pozitivno prirodno kretanje, ali negativni migracijski saldo. Budući da je migracijska komponenta kod njih dominantna, obje su zabilježile demografsku regresiju baš zahvaljujući migracijama.

Tablica 3. Migracijski saldo stanovništva NUTS 1, NUTS 2 i NUTS 3 regija Hrvatske između 2001. i 2011.*

Table 3. Net migration of the population of Croatian NUTS 1, NUTS 2 and NUTS 3 regions, 2001-2011

\begin{tabular}{lcccc}
\hline & $\begin{array}{c}\text { Međupopisna } \\
\text { promjena broja } \\
\text { stanovnika } \\
\text { 2001.-2011. }\end{array}$ & $\begin{array}{c}\text { Prirodna } \\
\text { promjena } \\
\text { između dva } \\
\text { popisa }\end{array}$ & $\begin{array}{c}\text { Migracijski } \\
\text { saldo }\end{array}$ & $\begin{array}{c}\text { Stopa } \\
\text { migracija } \\
\text { (\%) }\end{array}$ \\
\hline Zagrebačka & 7910 & -3231 & 11.141 & 3,6 \\
\hline $\begin{array}{l}\text { Krapinsko- } \\
\text { zagorska }\end{array}$ & -9540 & -7413 & -2127 & $-1,5$ \\
\hline Sisačko-moslavačka & -12.948 & -10.315 & -2633 & $-1,4$ \\
\hline Karlovačka & -12.888 & -9521 & -3367 & $-2,4$ \\
\hline Varaždinska & -8818 & -5455 & -3363 & $-1,8$ \\
\hline $\begin{array}{l}\text { Koprivničko- } \\
\text { križevačka }\end{array}$ & -8883 & -5437 & -3446 & $-2,8$ \\
\hline $\begin{array}{l}\text { Bjelovarsko- } \\
\text { bilogorska }\end{array}$ & -13.320 & -6681 & -6639 & $-5,0$ \\
\hline $\begin{array}{l}\text { Virovitičko- } \\
\text { podravska }\end{array}$ & -8553 & -3867 & -4686 & $-5,0$ \\
\hline Požeško-slavonska & -7797 & -2135 & -5662 & $-6,6$ \\
\hline Brodsko-posavska & -18.190 & -3130 & -15.060 & $-8,5$ \\
\hline Osječko-baranjska & -25.474 & -9787 & -15.687 & $-4,7$ \\
\hline $\begin{array}{l}\text { Vukovarsko- } \\
\text { srijemska }\end{array}$ & -25.247 & -3106 & -22.141 & $-10,8$ \\
\hline Međimurska & -4622 & -18 & -4604 & $-3,9$ \\
\hline $\begin{array}{l}\text { Grad Zagreb } \\
\text { Kontinentalna }\end{array}$ & $-\mathbf{1 3 7 . 4 9 8}$ & -75.806 & -61.692 & 2,1 \\
\hline $\begin{array}{l}\text { Primorsko- } \\
\text { goranska }\end{array}$ & -9310 & -10.238 & 928 & 0,3 \\
\hline & & & 16.582 & $-2,0$ \\
\hline
\end{tabular}




\begin{tabular}{|c|c|c|c|c|}
\hline & $\begin{array}{c}\text { Međupopisna } \\
\text { promjena broja } \\
\text { stanovnika } \\
2001 .-2011 .\end{array}$ & $\begin{array}{c}\text { Prirodna } \\
\text { promjena } \\
\text { između dva } \\
\text { popisa }\end{array}$ & $\begin{array}{l}\text { Migracijski } \\
\text { saldo }\end{array}$ & $\begin{array}{c}\text { Stopa } \\
\text { migracija } \\
(\%)\end{array}$ \\
\hline Ličko-senjska & -2750 & -4308 & 1558 & 2,9 \\
\hline Zadarska & 7972 & -175 & 8147 & 5,0 \\
\hline Šibensko-kninska & -3516 & -4908 & 1392 & 1,2 \\
\hline $\begin{array}{l}\text { Splitsko- } \\
\text { dalmatinska }\end{array}$ & -8878 & 3975 & -12.853 & $-2,8$ \\
\hline Istarska & 1711 & -4150 & 5861 & 2,8 \\
\hline $\begin{array}{l}\text { Dubrovačko- } \\
\text { neretvanska }\end{array}$ & -302 & 563 & -865 & $-0,7$ \\
\hline $\begin{array}{r}\text { Jadranska } \\
\text { Hrvatska }\end{array}$ & -15.073 & -19.241 & 4168 & 0,3 \\
\hline Hrvatska & -152.571 & -95.047 & -57.524 & $-1,3$ \\
\hline
\end{tabular}

* U ovoj tablici pojavljuje se uobičajeni problem usporedivosti podataka vezanih uz rezultate popisa stanovništva, desetljetnoga prirodnoga i mehaničkoga kretanja. Prirodno kretanje odnosi se na cijelu 2001. godinu, a izostavljena je 2011. Mehaničko kretanje izračunato je na temelju razlike broja stanovnika utvrđenog popisima stanovništva 2001. i 2011. koji se provode 31. ožujka popisne godine te prirodnoga kretanja u tom razdoblju. Pridodana je prirodna promjena za proa tri mjeseca 2001., dok u 2011. ta proa tri mjeseca prirodne promjene nisu obuhvaćena.

\section{STANOVNIŠTVO PREMA MIGRACIJSKIM OBILJEŽJIMA 2011.}

U analizi stanovništva prema migracijskim obilježjima koristit ćemo se podacima popisa stanovništva 2011., u kojem je bilo nekoliko pitanja o migraciji. Ključno pitanje za detekciju migrantskog stanovništva bilo je Živi li osoba neprekidno od rođenja u naselju popisa? Na one koji su se izjasnili da ne žive odnose se pitanja odakle se osoba doselila (naselje; općina/grad), godina doseljenja i razlog doseljenja. Bitno je napomenuti da popis bilježi samo posljednje migracijsko iskustvo pojedinca (posljednje preseljenje), ne ulazeći u migracijsku prošlost, tj. u moguća prijašnja preseljavanja, osim u slučajevima kada je osoba neko vrijeme živjela u inozemstvu. Ali ni tada se popisom ne bilježi ako se više puta selila u inozemstvu. U popisnici je u tom slučaju postojalo pitanje Je li osoba ikad boravila izvan RH godinu dana ili duže? Ako da, onda se pita i posljednja država u kojoj je osoba boravila, godina dolaskal povratka u $R H$ i razlog boravka u inozemstvu, gdje su ponuđena samo dva odgovora: rad (broj godina) i ostalo. 


\section{Domorodno i doseljeno stanovništvo}

Od ukupno 4.284.889 stanovnika Hrvatske nešto manje od polovine, 47,7\% (2.042.279), nije sudjelovalo u migraciji. Preciznije, tijekom života nikada se nije trajno preselilo iz naselja svog rođenja. Istovremeno je $\mathrm{u}$ migracijama sudjelovalo 2.239.355 (52,3\%) stanovnika Hrvatske, od čega 1.634.453 (73\%) u preseljavanju unutar RH, dok su se 604.902 stanovnika (27\%) doselila u RH iz inozemstva. Ako to usporedimo s podacima popisa 2001., jasno je da u tom segmentu migracijskih obilježja nije došlo gotovo ni do kakvih razlika jer je tada udio nemigrantskog stanovništva iznosio $48 \%$, udio doseljenih iz inozemstva $24,4 \%$, a $75,1 \%$ sudjelovalo je u unutrašnjim migracijama. ${ }^{19}$

Udio stanovnika koji tijekom života nisu nikada migrirali u Kontinentalnoj Hrvatskoj jest 48,2\%, a u Jadranskoj Hrvatskoj nešto manje, 46,5\%. Na razini NUTS 3 regija, županija, njihov udio kreće se između 40 i 60\%. Najveći udio nemigrantskog stanovništva imaju četiri županije Sjeverozapadne Hrvatske - Međimurska 57,8\%, Varaždinska 57,5\%, Krapinsko-zagorska $56,6 \%$ i Koprivničko-križevačka 55,2\%. Iz prikaza na slici 3 vidljivo je da su administrativne jedinice u nekadašnjim ratom zahvaćenim područjima prostori s najvećim udjelom doseljenog stanovništva. Tako najmanji udio nemigrantskog stanovništva imaju dvije županije - Šibensko-kninska, 41,1\%, i Sisačko-moslavačka, 41,6\%. Razlog tako malog udjela domorodnog stanovništva u tim županijama ratna su događanja devedesetih, kada je došlo do intenzivnih migracija na tim područjima. Usporedba s podacima iz 1991. govori da je tada u Šibensko-kninskoj županiji bilo nešto više od $60 \%$ domorodnog stanovništva, a u Sisačko-moslavačkoj nešto više od $50 \%{ }^{20}$

19 Od ukupno 4.437.460 stanovnika 2.298.045 od rođenja stanuje u istom naselju, 2.129.152 doselila su se u sadašnje naselje stanovanja, a za 10.707 nemamo podatke odakle su se doselili (Popis 2001., Stanovništvo prema migracijskim obilježjima, po gradovimalopćinama, Državni zavod za statistiku, Zagreb, www.dzs.hr).

20 Popis stanovništva, domaćinstava, stanova i poljoprivrednih gospodarstava 1991., Tablica 1.1.6, Stanovništvo prema migracijskim obilježjima, Državni zavod za statistiku, Zagreb. 


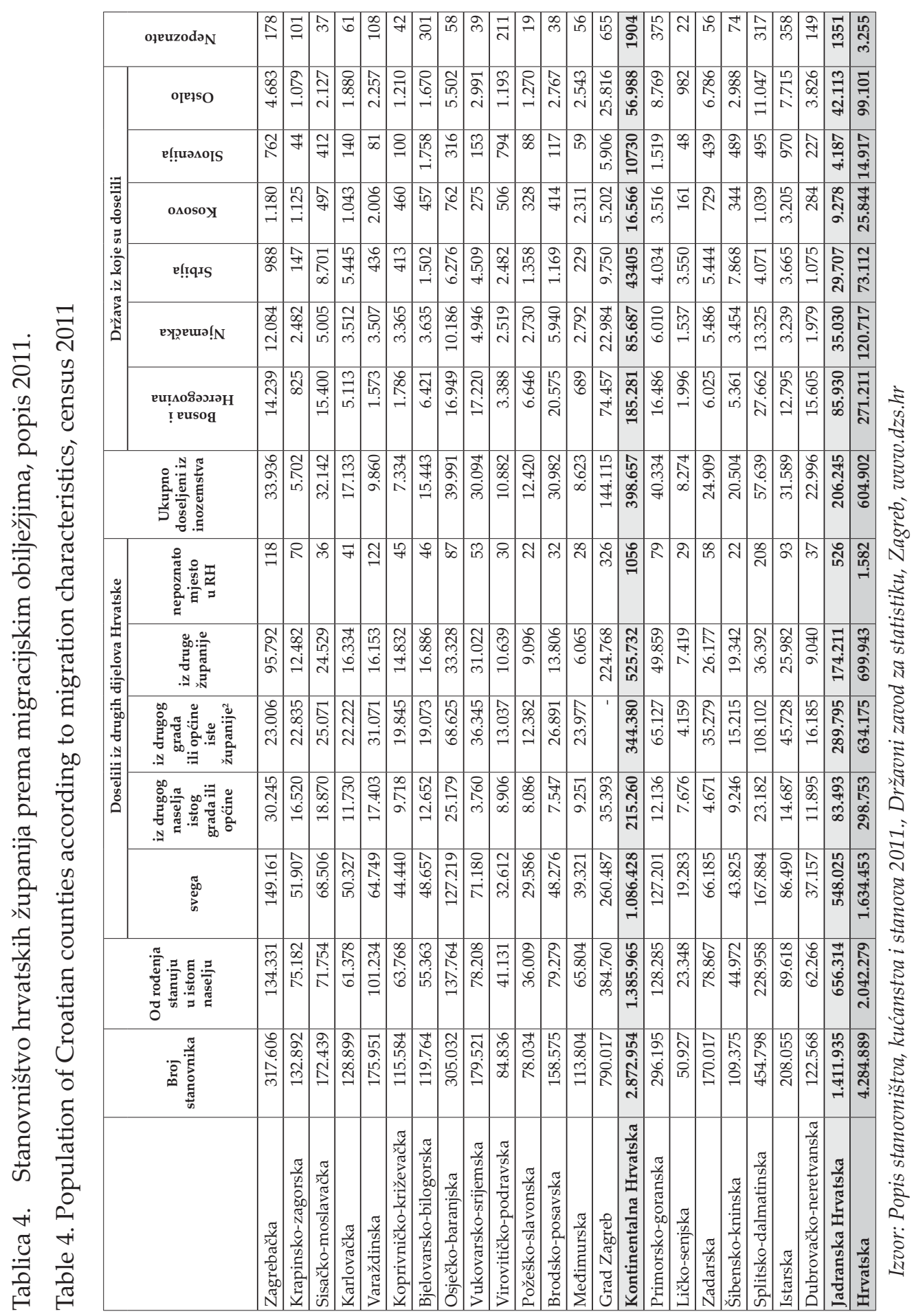


Slika 3. Gradovi i općine prema udjelu doseljenoga u ukupnome stanovništvu 2011.

Figure 3. Cities and municipalities according to the proportion of immigrants in the total population, 2011

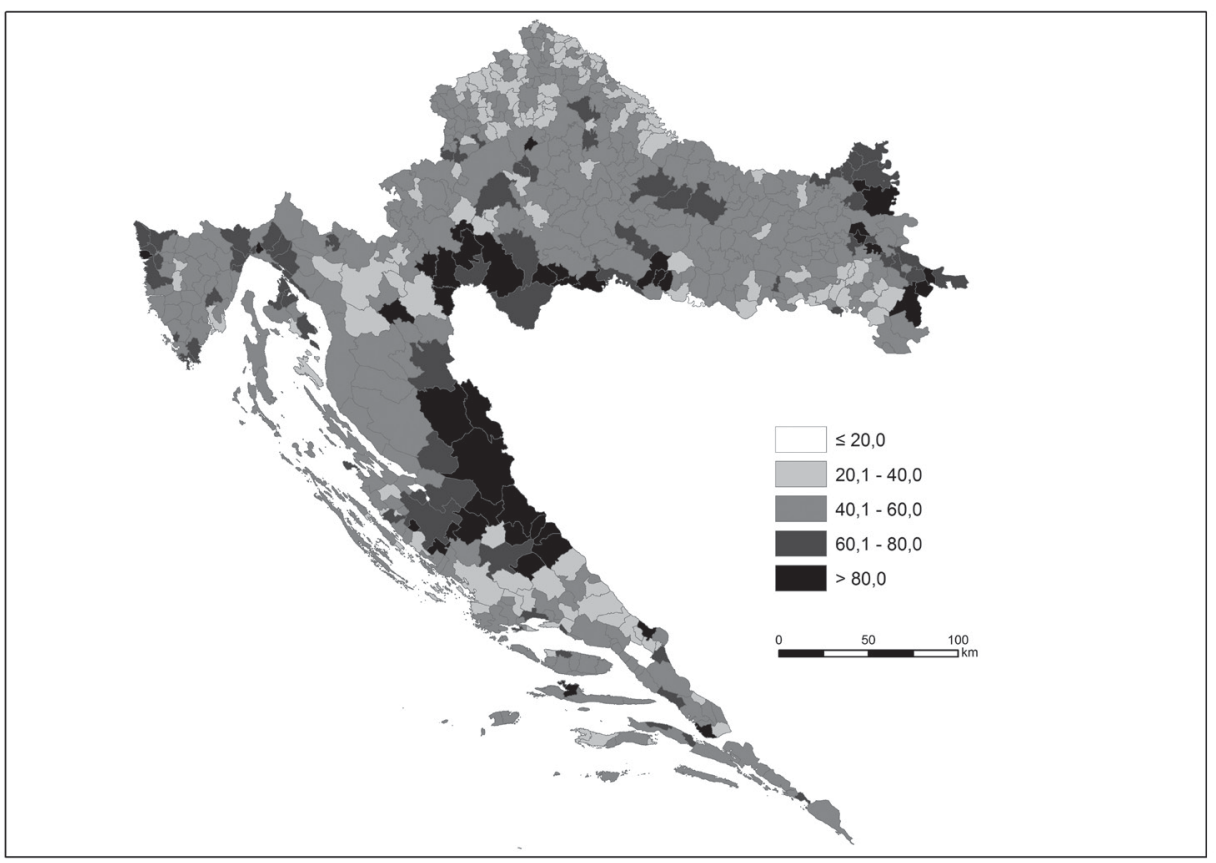

U Sisačko-moslavačkoj županiji, koja ima 58,4\% doseljenih, brojni su gradovi i općine s više od tri četvrtine doseljenog stanovništva: grad Glina, 81,8\%, grad Hrvatska Kostajnica, 85,6\%, općina Donji Kukuruzari, 82,8\%, općina Gvozd, 86,7\%, općina Hrvatska Dubica, 86,5\%, i općina Majur, $88,4 \%$. Od ukupno doseljenih u tu županiju trećina je $(31,9 \%)$ iz inozemstva. Od 32.142 doseljena iz inozemstva $47,9 \%$ je iz Bosne i Hercegovine, $27,1 \%$ iz Srbije, 15,6\% iz Njemačke i dr. Očito je takva struktura doseljenih rezultat povratničkih tokova emigranata iz ratnih godina i doseljavanja iz $\mathrm{BiH}$ zbog rata. Veliki udio doseljenih iz Njemačke većim je djelom generiran doseljavanjem Hrvata iz BiH koji su imali izbjeglički status u Njemačkoj. Slična je situacija i u Šibensko-kninskoj županiji, koja je 2011. na svom području zabilježila 64.329 doseljenika, od toga 31,9\% iz inozemstva. Najviše je doseljenih iz Srbije (7868), BiH (5361) te Njemačke (3454). Na razini gradova/općina brojni su oni koji imaju više od tri četvrtine doseljenika: grad 
Drniš, 71,7\%, grad Knin, 82,8\%, općina Biskupija, 80,8\%, općina Civljane, 87\%, općina Ervenik, 94,8\%, općina Kijevo, 92,8\%, općina Kistanje, 86,4\%, i općina Promina, $86,8 \%$. Dok je kod Drniša i Kijeva riječ o povratku raseljenih unutar Hrvatske ${ }^{21}$, kod Biskupije, Civljana, Ervenika i Kistanja riječ je o povratku Srba izbjeglih tijekom i nakon Oluje. ${ }^{22}$

Za razliku od njih visoki udio broja doseljenih 2011. u Zagrebačkoj (57,6\%), Istarskoj (56,8\%) i Primorsko-goranskoj županiji $(57,6 \%)$ većim je dijelom uvjetovan njihovom gospodarskom atraktivnošću. Naselja Zagrebačke županije posebno su atraktivna migrantima zbog jeftinijeg i kvalitetnijeg stanovanja u blizini velikoga grada, pa se čak 52,3\% doselilo iz druge županije. Dio toga kontingenta odnosi se na stanovništvo koje se preselilo iz grada Zagreba u okolicu.

\section{Migracije prema udaljenosti}

Za prostornu analizu migracija iz rezultata popisa 2011. dostupni su podaci o lokalnome (doseljeni iz drugog naselja istoga grada ili općine), unutaržupanijskom (doseljeni iz drugoga grada ili općine iste županije) i međužupanijskom preseljenju (doseljeni iz druge županije). Osim unutardržavnih migracija dostupni su i podaci o ukupnom broju doseljenih iz inozemstva te o državama iz kojih su se doselili. U strukturi unutrašnjih migracija prema prostornoj komponenti, najviše je migranata sudjelovalo u međužupanijskim preseljenjima (42,8\% ili 699.943), samo nešto manje u unutaržupanijskim (38,8\% ili 634.175), dok je znatno manji udio lokalnih preseljenja, među naseljima istoga grada ili općine, svega 18,3\% (298.753). $\mathrm{S}$ obzirom na to da je u unutarnjim migracijama prevladavalo doseljavanje iz druge županije, možemo govoriti o dominaciji veće migracijske distance unutarnjih migracija.

Deset godina prije, 2001., ti prostorni odnosi bili su otprilike isti. I tada je doseljavanje iz drugog naselja istoga grada ili općine bila najslabije zastupljena migracijska distanca unutarnjih migracija, pa je u njoj sudjelovalo tek 300.548 ili 18,8\% ukupnog broja migranata unutar Hrvatske. U unutaržupanijskim migracijama participiralo je njih 589.247 ili 36,9\%, a u međužupanijskima 708.735 ili 44,3\%. Razlog intenzivnijim međužupanijskim migracijama možemo pronaći u slabo razvijenoj urbanoj mreži i neadekvatnome ekonomskom razvoju gradskih centara u pojedinim županijama, čime je u

${ }_{21}$ Od ukupno doseljenih u općinu Drniš 90,3\% doselilo se iz nekog naselja u Hrvatskoj, u općini Kijevo njihov je udio 92,2\%, a u općini Promina 91,5\% (popis 2011.).

22 Od ukupno doseljenih iz inozemstva, iz Srbije se doselilo 86,9\% u općinu Biskupija, 90,1\%, u općinu Civljane te 78,6\% u općinu Kistanje (popis 2011.). 
prošlosti, ali i danas bio ograničen prihvat deagrariziranog stanovništva iz okolnih ruralnih naselja koje je tražilo zaposlenje u sekundarnim i tercijarnim djelatnostima. Stoga se to stanovništvo često trajno iseljavalo u velike gradske centre izvan matične županije. To je jedan od osnovnih razloga neravnomjernog razmještaja stanovništva, ali i velikih regionalnih razlika u društveno-gospodarskom razvoju.

Osim podataka o unutrašnjoj migraciji iz popisâ stanovništva, moguće ih je analizirati i iz godišnjih priopćenja o migraciji DZS-a. Za razliku od brojnih nepravilnosti i nedosljednosti u prikupljanju podataka o vanjskim migracijama, godišnja izvješća o migracijskim tokovima unutar države možemo smatrati relativno pouzdanima. Iz njih je očito da taj oblik migracija tijekom promatranog razdoblja ne pokazuje snažnije oscilacije. Od 2001. do 2013. najmanje je bilo preseljenja na najkraću udaljenost (među naseljima istoga grada/općine), najviše je preseljenja na najveću udaljenost (među županijama), a samo je malo manje prostornih kretanja unutar županija (tablica 5).

Tablica 5. Unutarnje migracije u Hrvatskoj 2001. - 2013.

Table 5. Internal migrations in Croatia, 2001-2013

\begin{tabular}{lcccccccc}
\hline & & & \multicolumn{5}{c}{ Preseljeno stanovništvo } \\
\cline { 3 - 9 } & Ukupno & \multicolumn{2}{c}{$\begin{array}{c}\text { među naseljima } \\
\text { istoga } \\
\end{array}$} & brada/općine & $\begin{array}{c}\text { među gradovima/ } \\
\text { općinama } \\
\text { iste županije }\end{array}$ & \multicolumn{2}{c}{$\begin{array}{c}\text { među } \\
\text { županijama }\end{array}$} \\
\cline { 2 - 9 } 2001. & 73.089 & 100 & 13.931 & 19,1 & 28.313 & 38,7 & 30.845 & 42,2 \\
\hline 2002. & 77.154 & 100 & 14.847 & 19,2 & 29.465 & 38,2 & 32.842 & 42,6 \\
\hline 2003. & 84.444 & 100 & 18.545 & 22,0 & 32.610 & 38,6 & 33.289 & 39,4 \\
\hline 2004. & 79.800 & 100 & 16.993 & 21,3 & 30.930 & 38,8 & 31.877 & 39,9 \\
\hline 2005. & 78.018 & 100 & 16.464 & 21,1 & 30.224 & 38,7 & 31.330 & 40,2 \\
\hline 2006. & 80.757 & 100 & 17.999 & 22,3 & 30.747 & 38,1 & 32.011 & 39,6 \\
\hline 2007. & 82.678 & 100 & 18.369 & 22,2 & 31.891 & 38,6 & 32.418 & 39,2 \\
\hline 2008. & 75.047 & 100 & 16.301 & 21,7 & 29.189 & 38,9 & 29.557 & 39,4 \\
\hline 2009. & 71.353 & 100 & 16.136 & 22,6 & 27.419 & 38,4 & 27.798 & 39,0 \\
\hline 2010. & 66.739 & 100 & 15.008 & 22,5 & 25.885 & 38,8 & 25.846 & 38,7 \\
\hline 2011. & 71.403 & 100 & 15.653 & 21,9 & 27.236 & 38,1 & 28.514 & 39,9 \\
\hline 2012. & 68.839 & 100 & 14.314 & 20,8 & 26.908 & 39,1 & 27.617 & 40,1 \\
\hline 2013. & 76.840 & 100 & 16.827 & 21,9 & 30.054 & 39,1 & 29.959 & 39,0 \\
\hline
\end{tabular}

Izvor: Migracija stanovništva Republike Hrvatske u 2013., Priopćenje 7.1.2., Državni zavod za statistiku, Zagreb, 2014.; Migracija stanovništva Republike Hrvatske u 2004., Priopćenje 7.1.2., Državni zavod za statistiku, Zagreb, 2005. 
Popis 2011. pokazuje iznimno veliki udio međužupanijskih migracija za Grad Zagreb, 86,3\%, te Zagrebačku županiju, 64,2\%. To je lako objašnjivo jer je praktično Zagrebačka županija okolica samoga grada Zagreba, a između njih je intenzivan migracijski proces. Osim toga Grad Zagreb kao najznačajnije gospodarsko središte u Hrvatskoj već je desetljećima najatraktivniji migrantima. Istovremeno je Međimurska županija migracijski najneatraktivnija, što potvrđuje i najmanji udio doseljenog stanovništva, te ima najslabiju međužupanijsku migraciju. Iz drugih županija u nju se doselilo samo $15,4 \%$ doseljenika.

Od 2002. do 2013. sedam županija ima pozitivni međužupanijski migracijski saldo: Grad Zagreb (12.267), Zagrebačka županija (16.675), Zadarska (8075), Istarska (6302), Primorsko-goranska (3019), Šibensko-kninska (673) i Ličko-senjska (270). Može se zaključiti da su i dalje migrantima najprivlačnije županije s većim gospodarskim centrima i jačom ekonomskom snagom. Očekivano se najviše napuštaju županije koje su ekonomski u najnepovoljnijem položaju, Vukovarsko-srijemska (-9130) i Brodsko-posavska (-7832).

Prema popisu 2011., u Hrvatskoj žive 604.902 osobe doseljene iz inozemstva i čine $27 \%$ migrantskog stanovništva te $13,6 \%$ ukupnog stanovništva RH. Veliki je broj županija u kojima su 2011. u kontingentu doseljenih otprilike trećinu činili oni iz inozemstva. U Brodsko-posavskoj je županiji 39,1\% »inozemaca « među doseljenicima, Dubrovačko-neretvanskoj 38,2\%, Gradu Zagrebu 35,6\%, Vukovarsko-srijemskoj 34\%, Šibensko-kninskoj i Sisačkomoslavačkoj 31,9\% te u Ličko-senjskoj 30\%.

Najviše je doseljenih iz $\mathrm{BiH}, 271.211$, kao rezultat starije radne migracije i novije migracije zbog rata $\mathrm{u} \mathrm{BiH}$. Više od polovine ukupne negativne bilance međurepubličke migracije $\mathrm{BiH}$ je ostvarivala s Hrvatskom, pa se od 1971. do 1981. prosječno godišnje iz BiH iseljavalo 8200 stanovnika u RH, a 1700 doseljavalo iz RH u BiH (Markotić, 2000). U apsolutnim brojevima 2011. njihova najveća koncentracija bila je u Splitsko-dalmatinskoj županiji (27.662) i Brodsko-posavskoj (20.575), kamo su se u najvećem broju doselili devedesetih. ${ }^{23}$ I dok je u Splitsko-dalmatinskoj županiji doseljavanje, iako manjeg obujma, nastavljeno i u prvom desetljeću 21. stoljeća (2001. - 2011. g. 6185 doseljenih), u Brodsko-posavskoj ono je značajno smanjeno (2001. 2011. g. 1063 doseljenih).

Zanimljivost je veliki broj doseljenih iz Njemačke. Dijelom je riječ o povratku u Hrvatsku nakon "gastarbajterskih godina« rada i umirovljenja, ali

23 U Splitsko-dalmatinsku županiju od 1991. do 2000. doselilo se 9210 stanovnika iz BiH, što čini trećinu toga kontingenta. U Brodsko-posavskoj županiji u tom se razdoblju nastanilo 10.239 stanovnika BiH, od čega u prvom razdoblju devedesetih (1991. - 1995.) čak 9305. 


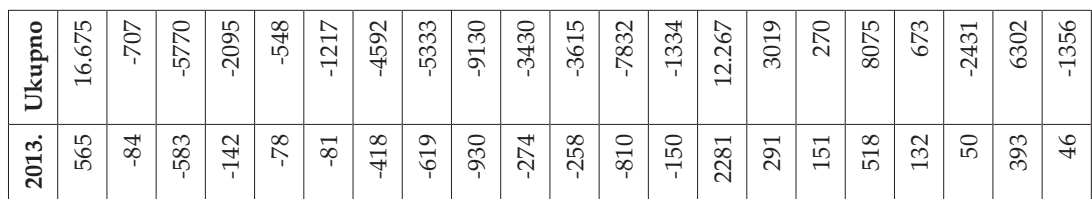

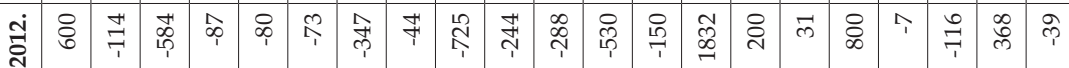

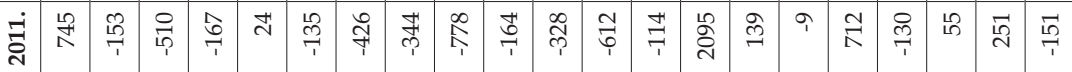

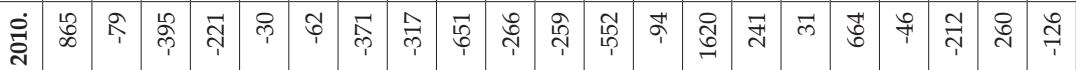

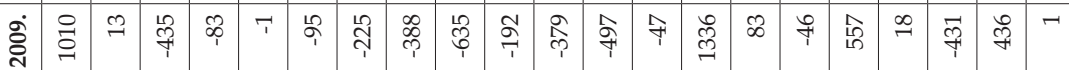

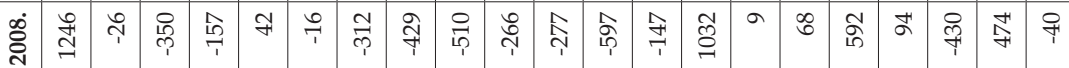

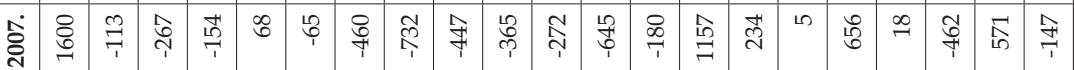

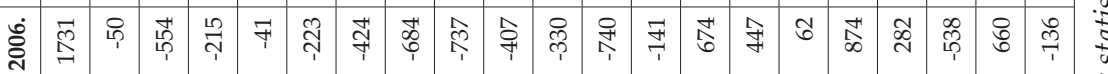


i o useljenju uglavnom Hrvata iz BiH koji su radili u Njemačkoj ili su tamo otišli kao izbjeglice. No ti procesi teško mogu objasniti broj od 120.717 doseljenika iz Njemačke ako znamo da je u popisu 2001. zabilježeno samo 9046 doseljenika iz te države. Zar je zaista moguće da se u desetogodišnjem razdoblju između popisa u Hrvatsku doselilo 110.000 osoba iz Njemačke? Podaci o razdobljima doseljavanja pokazuju da je to nemoguće jer se u posljednjemu međupopisnom razdoblju u RH doselilo 28.986 ljudi iz Njemačke. Kako je moguće da je popis 2001. zabilježio samo 4551 doseljenika (1991. - 2001.), a deset godina poslije prema popisu se u tom razdoblju doselilo deset puta više ljudi iz Njemačke, 47.113? Očito je riječ o metodološkim nedosljednostima dvaju popisa! Takve nedosljednosti možemo primijetiti i u drugim zemljama, primjerice Austriji, iz koje se, navodno, prema popisu 2011., doselilo 13.609 migranata, a 2001. samo 1381; u Švicarskoj 2011. g. 11.342 doseljenih, a 2001. g. 995. Kada usporedimo razdoblja doseljavanja, proizlazi da se u posljednjemu međupopisnom razdoblju iz tih zemalja doselilo nešto više od 4000 migranata. Postavlja se istraživačko pitanje je li riječ o popisivanju stanovništva koje realno živi u inozemstvu, a opet se popisalo u RH. Time se još jednom potvrđuje već poznata činjenica da je statistika vanjske migracije najnepouzdaniji segment službene statistike.

Prema popisu 2011., iz Srbije se doselilo 73.112 stanovnika, iz Slovenije 25.844 te s Kosova 14.917. Ako to usporedimo s podacima iz 2001., također uočavamo slične nedosljednosti. Ipak, razlog porasta broja doseljenih iz Srbije realan je i lako objašnjiv: riječ je o povratku izbjeglica koje su se zbog rata iselile iz Hrvatske i kroz organizirani manjinski povratak ponovno se nastanile u RH. 


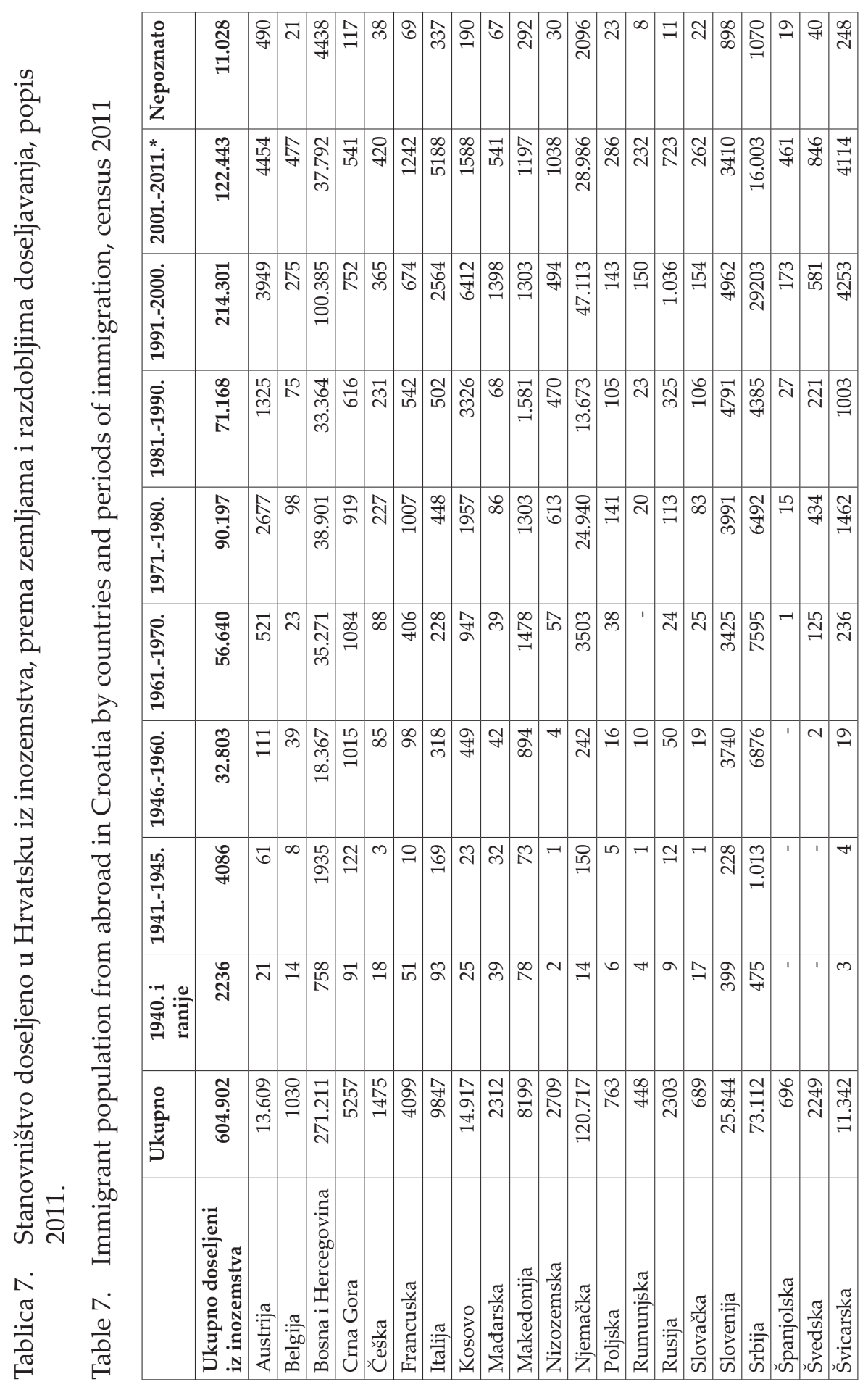




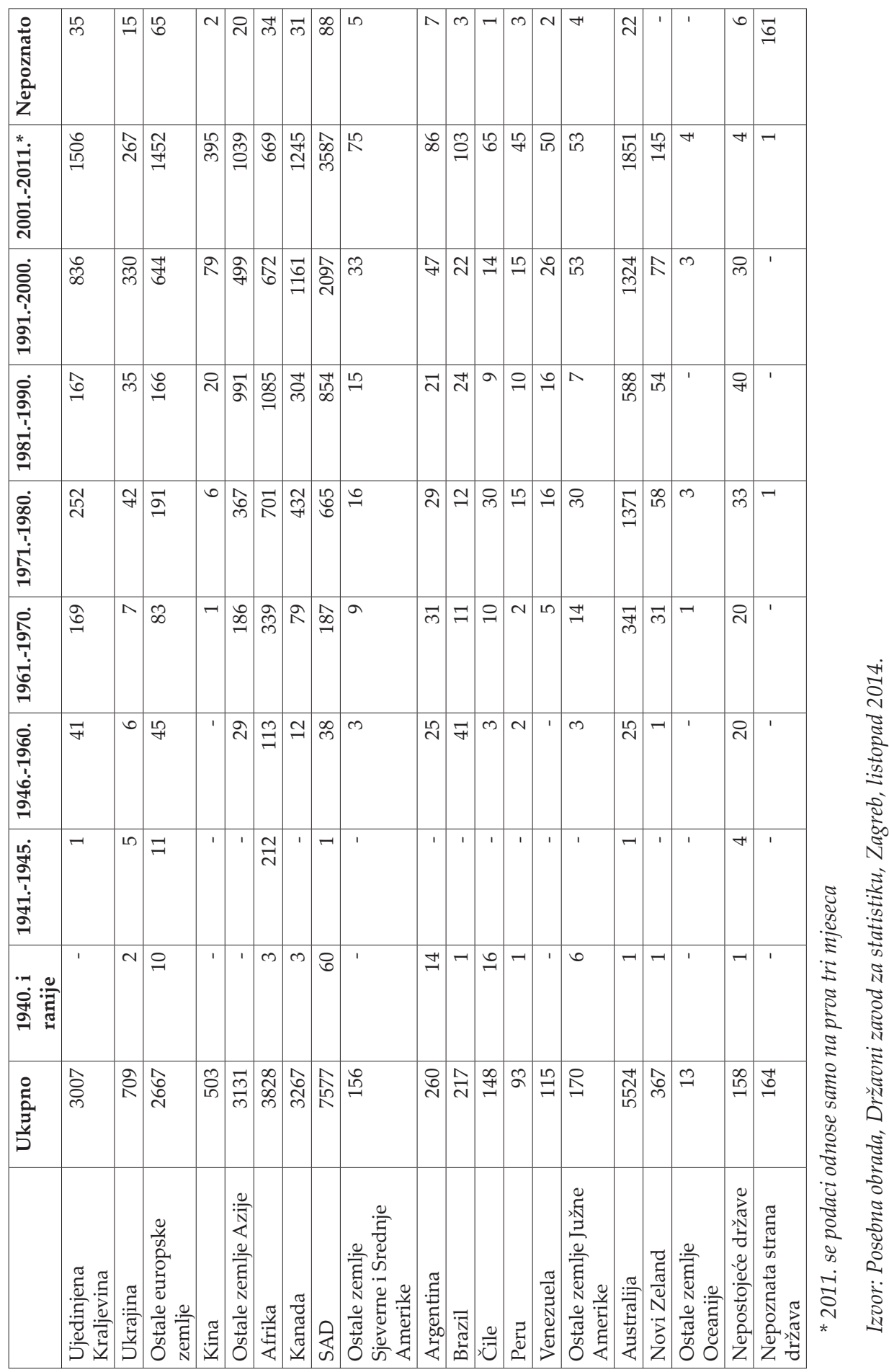




\section{Rođeni u inozemstvu}

Prema popisu 2011., u Hrvatskoj živi 584.947 osoba rođenih u inozemstvu, što čini $13,7 \%$ ukupnog stanovništva. ${ }^{24}$ Među županijama se izdvajaju četiri s izrazito velikim udjelom stanovništva rođenog u inozemstvu: Brodsko-posavska, 21,3\%, Vukovarsko-srijemska, 19,1\%, Dubrovačko-neretvanska, 19,1\%, i Grad Zagreb, 17,5\%. Za razliku od njih mali udio rođenih u inozemstvu imaju Krapinsko-zagorska, 3,1\%, Varaždinska, 4\%, Međimurska, 4,7\% i Koprivničko-križevačka, 5,1\%.

Od ukupnog broja rođenih u inozemstvu većina njih (70\%) rođena je u $\mathrm{BiH}$ (409.357), što je rezultat radnih migracija tijekom socijalističkog razdoblja i useljavanja uzrokovanih ratom $\mathrm{u} \mathrm{BiH}$. Ako analiziramo doseljavanje iz BiH prije rata, u Hrvatskoj je 1991. živjelo 318.000 stanovnika rođenih u $\mathrm{BiH}$, od kojih je četvrtina živjela na području Grada Zagreba, a veća koncentracija još je bila u Vukovarsko-srijemskoj (12,5\% svih rođenih u $\mathrm{BiH}) \mathrm{i}$ Osječko-baranjskoj županiji (10,1\%). U razdobljima nakon Drugoga svjetskog rata migracija u Hrvatsku bila je potaknuta ekonomskom razvijenošću i usmjerena najvećim dijelom $u$ tadašnja gospodarska, točnije industrijska središta, gdje se tražila brojna radna snaga. U tadašnjim imigracijskim tokovima u RH, iz BiH se doseljavalo stanovništvo različitih nacionalnosti, iako su očekivano prevladavali Hrvati (1991. g. 193.349 Hrvata rođenih u BiH). Dio Hrvata preseljavao se u RH ne samo iz ekonomskih razloga nego i iz želje da živi u Hrvatskoj, koju su doživljavali kao svoju domovinu. Pepeonik (2000) navodi da je najveća emigracija bila iz sjevernih krajeva $\mathrm{BiH}$, od Bihaća do Brčkog, i s jugozapada, od Livna do Ljubuškog. Godine 2011. među rođenima u inozemstvu značajno je velik udio rođenih u BiH u Brodskoposavskoj županiji $(87,7 \%)$, Požeško-slavonskoj (82\%), Sisačko-moslavačkoj $(83,1 \%)$ i Dubrovačko-neretvanskoj (80,7\%). Možemo reći da su to »ulazne« županije, najbliže pograničnim područjima $\mathrm{BiH}$, iz kojih je iseljavanje prema Hrvatskoj bilo najintenzivnije.

$\mathrm{U}$ znatno manjem udjelu među rođenima u inozemstvu sudjeluju rođeni u Srbiji, 9\% (52.763), u Njemačkoj, 5,8\% (34.148), na Kosovu, 3,5\%, u Sloveniji, 3,4\%, Makedoniji, 1,7\%, te u ostalim zemljama, 6,6\% (popis 2011.). U Međimurskoj županiji, koja je na samom sjeveru Hrvatske, samo je 20,4\% rođenih $\mathrm{u}$ inozemstvu rođeno $\mathrm{u} \mathrm{BiH}$. Istovremeno je $\mathrm{u}$ toj županiji relativno gledajući zabilježen najveći broj rođenih u Njemačkoj u usporedbi s drugim županijama, čak $19,6 \%$. S obzirom na to da se ta županija do sada nije

24 Dvadeset godina prije, 1991., 10,6\% ukupnog stanovništva $\mathrm{RH}$ (508.674) bilo je rođeno u inozemstvu. 


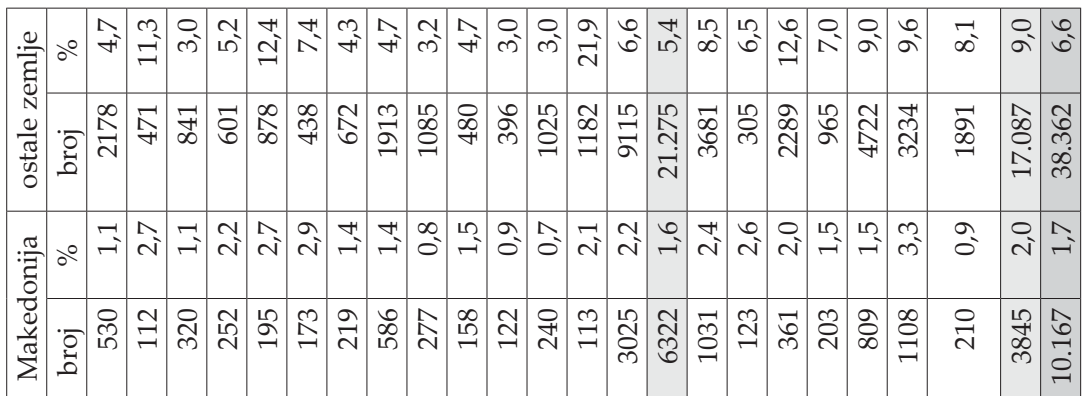

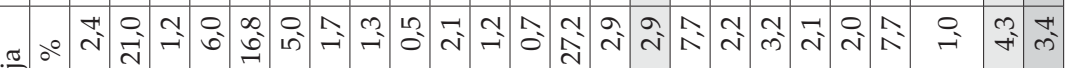
के

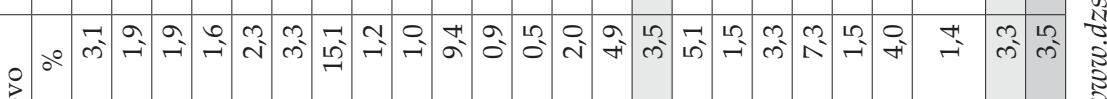

مि கิ

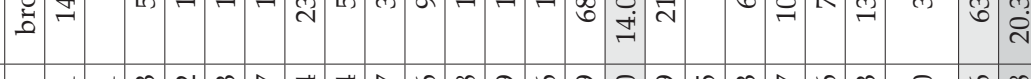

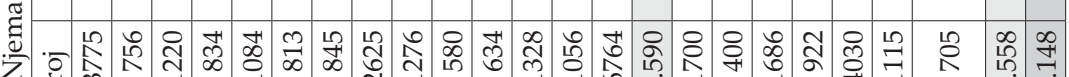

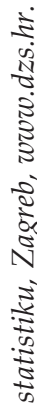

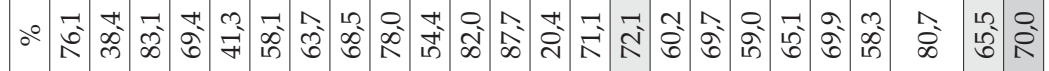

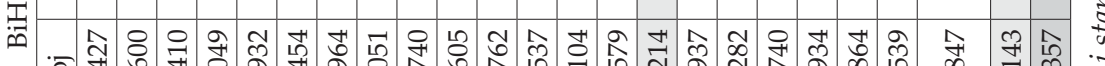

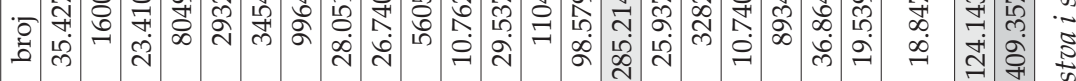

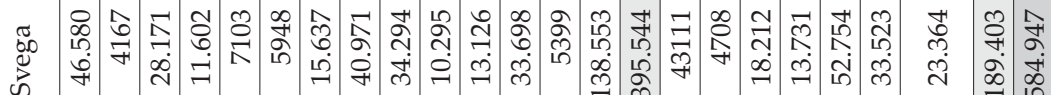
䒹 告 (1)

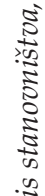


pokazala atraktivnom za doseljavanje "stranaca«, očito je riječ o povratnoj migraciji radnika s privremenog rada u inozemstvu i njihovoj djeci rođenoj u Njemačkoj. U toj županiji zabilježen je i najveći udio rođenih u Sloveniji, $27,2 \%$, što je dobar pokazatelj jake pogranične povezanosti i migracija, dobrim dijelom udajno-ženidbenih. Slična je situacija i u još dvije županije koje graniče sa Slovenijom, Krapinsko-zagorskoj (udio rođenih u Sloveniji među rođenim u inozemstvu 21,0\%) i Varaždinskoj (16,8\%). Te dvije županije također pokazuju i veliki udio rođenih u Njemačkoj, u Krapinsko-zagorskoj 18,1\% i u Varaždinskoj 15,3\% svih rođenih u inozemstvu. Istovremeno u Virovitičko-podravskoj je županiji relativno najveći udio rođenih u Srbiji, 22,2\%, dok ih je najmanje u Brodsko-posavskoj, 3,5\%.

\section{Razdoblja doseljavanja}

Osim po obujmu migracije možemo analizirati i s obzirom na vremenske intervale u kojima su se odvijale. U posljednjemu promatranom razdoblju u Hrvatskoj su 559.734 stanovnika promijenila mjesto stanovanja, od čega su $55,2 \%$ bile žene. U strukturi ukupnih migracija u tom razdoblju 78,1\% čine unutrašnje migracije, a 21,9\% migracije iz inozemstva. U unutrašnjim migracijama najviše je preseljenja unutar iste županije (262.979 ili 60,1\%), dok je nešto manji broj migranata tijekom preseljenja prešao županijsku granicu, $174.312(39,9 \%)$.

Od ukupnog broja doseljenika u posljednjemu međupopisnom razdoblju od 2001. do 2011. iz inozemstva se doselilo njih 122.443, što je u usporedbi s prethodnim međupopisnim razdobljem smanjenje od gotovo $50 \%$ (tablica 9). Devedesetih se u Hrvatsku doselio čak 214.301 stanovnik, od toga 149.989 u Kontinentalnu, a 64.312 u Jadransku, kao izravna posljedica ratova na području zemalja bivše Jugoslavije. I u tom je razdoblju najznačajnije ishodište migranata bila Bosna i Hercegovina, kao i u prethodnim razdobljima, samo što su tada razlozi bili socioekonomski, a devedesetih ratni.

Za razliku od svih prijašnjih razdoblja, kada su migracije uglavnom bile generirane ekonomskim razlozima, devedesetih je većinom riječ o prisilnim ratnim migracijama, a u prvome desetljeću 21. stoljeća o kombinaciji ekonomskih i povratnih izbjegličkih, jer se odvija manjinski povratak. Podatak o broju doseljenih iz inozemstva u posljednjemu međupopisnom razdoblju demografima je posebno interesantan jer utječe na promjenu ukupnog broja stanovnika. Od 2001. do 2011. u Kontinentalnu Hrvatsku doselilo se iz inozemstva 69.225 stanovnika, a u Jadransku 53.218. I dok je u prijašnjim razdobljima doseljavanja otprilike podjednak udio doseljenih u obje NUTS 2 regije, devedesetih se u Kontinentalnu Hrvatsku doselilo 37,6\% od svih 


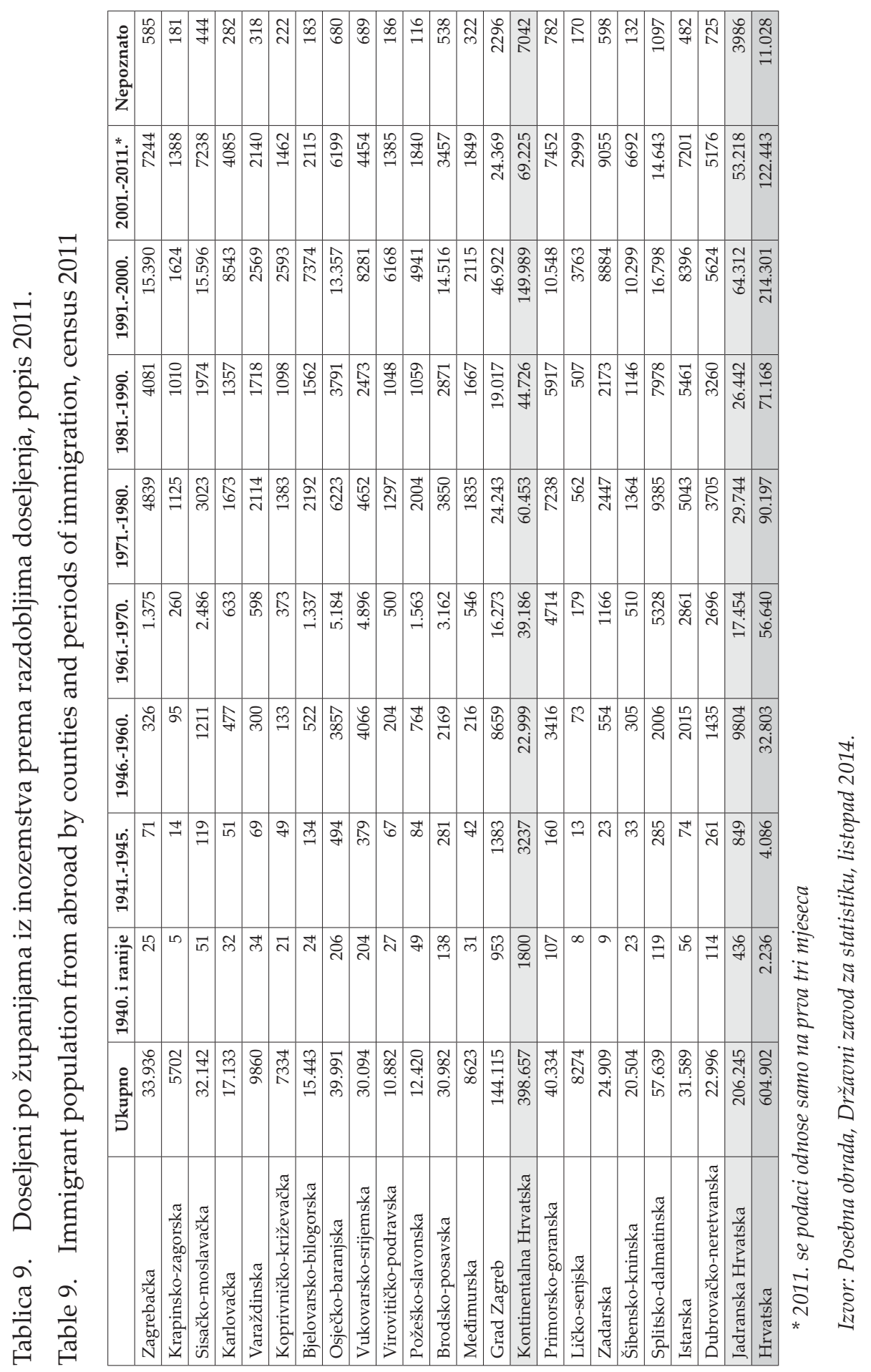


ukupno doseljenih iz inozemstva u Hrvatsku, a u Jadransku 31,2\%. Razlika je uočljiva i u prvome desetljeću 21. stoljeća, ali je relativno gledajući sada jadranski dio RH migracijski atraktivniji: od svih doseljenih iz inozemstva u tu regiju čak se četvrtina $(25,8 \%)$ doselila u posljednjemu međupopisnom razdoblju.

Najveći broj imigranata iz inozemstva u tom razdoblju doselio se u Grad Zagreb (24.369) i Splitsko-dalmatinsku županiju (14.643). Najviše migranata u relativnim udjelima imala je Ličko-senjska županija, 36,2\% svih doseljenika iz inozemstva koji žive na tom području doselilo se u posljednjih desetak godina, a čak 45,5\% u devedesetima. Tako veliki udio migrantskog stanovništva u posljednjih dvadesetak godina u županiji koja ima daleko najmanju gustoću naseljenosti u Hrvatskoj većim je dijelom rezultat manjinskog povratka, uglavnom Srba koji se vraćaju iz Srbije i manjim dijelom iz BiH ili nekih drugih država, te manjim dijelom doseljavanja Hrvata iz $\mathrm{BiH}$. Gotovo je identična situacija i u dvije susjedne županije; u Zadarsku se $u$ tom razdoblju doselilo $36,4 \%$ svih doseljenih iz inozemstva, a u Šibensko-kninsku 32,6\%. Da je također riječ o manjinskom povratku, potvrđuju podaci da se u Zadarskoj županiji od 9055 doseljenih iz inozemstva u tom razdoblju 27,9\% doselilo iz Srbije, a u Šibensko-kninskoj od 6692 doseljenika 42,3\% prethodno je stanovalo u Srbiji.

\section{ZAKLJUČAK}

U posljednjemu međupopisnom razdoblju 2001. - 2011. usprkos iskazanim brojnim metodološkim statističkim nedorečenostima i nedoumicama utvrđeno je da stanovništvo Hrvatske (NUTS 1) i nadalje proživljava depopulacijske procese. I u obje statističke regije (NUTS 2) opće kretanje broja stanovnika obilježava depopulacija, koja je nešto slabija u Jadranskoj nego u Kontinentalnoj Hrvatskoj. Za razliku od devedesetih godina 20. stoljeća primarni razlog nepovoljnih demografskih procesa jest negativno prirodno kretanje. S obzirom na nepovoljnu dobno-spolnu strukturu i nastavak iseljavanja možemo očekivati daljnje slabljenje vitalnosti stanovništva.

I u posljednjemu međupopisnom razdoblju negativni selidbeni saldo svrstava Republiku Hrvatsku u tradicionalno iseljeničku zemlju, što će uz negativnu prirodnu promjenu i ubuduće znatno pridonositi produbljivanju demografske krize. Ekonomske poteškoće iz tranzicijskog razdoblja i Domovinskog rata te ekonomska kriza posljednjih šest godina, čimbenici su koji su oblikovali vrlo tešku ekonomsku situaciju u Hrvatskoj, što će i dalje biti važan potisni čimbenik za emigraciju, uglavnom mlađega reproduk- 
tivnog stanovništva. Povratničke migracije izbjeglih iz Hrvatske uglavnom su završile i realno je da će se one sljedećih nekoliko godina odvijati u vrlo malom obujmu (povratak pojedinaca) te neće značajnije utjecati na demografsko stanje i procese. Osim toga Bosna i Hercegovina kao tradicionalno ishodište doseljenika u Hrvatsku također demografski slabi te se stoga značajno smanjio i kontingent potencijalnih doseljenika iz te zemlje.

Iz migracijskih podataka očito je da se Hrvatska demografski polarizirala na Zagreb i okolicu kao gospodarsko i demografsko središte države te na priobalne županije, koje gospodarski razvoj i donekle migracijsku atraktivnost temelje uglavnom na još uvijek ekonomski atraktivnom turizmu. Većina županija Kontinentalne Hrvatske čini slabo razvijena, periferna područja depopulacije i općenito demografskog nazadovanja. Očito se i na početku 21. stoljeća nastavlja dominacija Zagreba, dok dosadašnji pokušaji regionalno uravnoteženijeg razvoja nisu dali očekivane rezultate. Posebno je to slučaj sa županijama čiji je dio teritorija bio okupiran ili opustošen u ratu, a koje su i dotada pokazivale negativne demografske tendencije. Propast malih industrija u nekadašnjim općinskim centrima, dok se istovremeno nisu otvarala nova radna mjesta $u$ drugim djelatnostima, uništila je i posljednje mogućnosti zaposlenja kojim bi se barem zadržala postojeća populacija. Sve to rezultiralo je još jačom depopulacijom i starenjem te sve jačim ekonomskim zaostajanjem i dotada demografski deficitarnih područja. I dalje su najveće mogućnosti zaposlenja uglavnom u velikim gradskim središtima, što migrante nastavlja usmjerivati prema njima.

\section{LITERATURA}

Klempić Bogadi, S. i Podgorelec, S. (2009). Sociodemografske značajke i procesi u hrvatskim obalnim gradovima, Geoadria, 14 (2): 221-247.

Klempić Bogadi, S. (2010). Populacijski razvoj gradskih regija Hrvatske 1948. - 2001. u: I. Lajić (ur.). Migracije i regionalni razvoj Hrvatske. Zagreb: Institut za migracije i narodnosti, 30-76.

Lajić, I. (2002). Hrvatske migracije početkom 21. stoljeća, Migracijske i etničke teme, 18 (2-3): 135-149.

Maleković, S. i Jurlin, K. (2012). Novo definiranje neadministrativnih regija NUTS 2 razine u Republici Hrvatskoj, Informator, 6108-6109: 1-3, http://www.irmo.hr/wpcontent/uploads/2013/12/Informator-6108-6109-web.pdf (14. 10. 2014.).

Magaš, D. (2011). Koncept teritorijalnog ustroja Jadranske Hrvatske, Geoadria, 16 (2): 211-236. 
Markotić, A. F. (2000). Utjecaj ratnog egzodusa iz BiH na promjene u ukupnom broju stanovnika Hrvatske 1991.-1997. godine, u: D. Pejnović (ur.). Zbornik radova 2. hrvatskog geografskog kongresa. Zagreb: Hrvatsko geografsko društvo, 213-221.

Mesić, M. i Bagić, D. (2011). Manjinski povratak u Hrvatsku - studija otvorenog procesa. Zagreb: UNHCR.

Ministarstvo regionalnog razvoja, šumarstva i vodnoga gospodarstva Republike Hrvatske (2010). Strategija regionalnog razvoja Hrvatske 2011. - 2013., http://www. mrrfeu.hr/UserDocsImages/STRATEGIJA_REGIONALNOG_RAZVOJA.pdf， (17. 06. 2014.).

Mišetić, R. (2002). Utjecaj prisilnih migracija na promjenu biološkog sastava stanovništva - primjer Sisačko-moslavačke županije, Migracijske i etničke teme, 18 (4): 307-317.

Mrđen, S. (2014). Glavne odrednice ukupnog kretanja stanovništva Hrvatske, 1991.2001., 2001.-2011., u: A. Akrap, I. Čipin i M. Strmota (ur.). Zbornik radova znanstvenog skupa Demografija u Hrvatskoj. Zagreb: Ekonomski fakultet, 407-426.

Nejašmić, I. (1988). Migracijski saldo stanovništva seoskih naselja SR Hrvatske 19611981, Migracijske teme, 4 (3): 311-330.

Nejašmić, I. (1994). Hrvatski građani na radu u inozemstvu: razmatranje popisnih podataka 1971, 1981. i 1991., Migracijske teme, 10 (2): 139-156.

Njegač, D. (2000). Regionalna struktura Hrvatske, u: D. Pejnović (ur.). Zbornik radova 2. hrvatskog geografskog kongresa. Zagreb: Hrvatsko geografsko društvo, 191-199.

Pepeonik, Z. (2000). Stanovništvo RH 1991. godine rodom iz BiH, u: D. Pejnović (ur.). Zbornik radova 2. hrvatskog geografskog kongresa. Zagreb: Hrvatsko geografsko društvo, 201-212.

Podgorelec, S. i Klempić, S. (2007). Starenje i neformalna skrb o starim osobama u Hrvatskoj, Migracijske i etničke teme, 23 (1-2): 111-134.

Sić, M. (2003). Regional Disparities in Croatia, Hrvatski geografski glasnik, 65 (2): 5-28.

Šantić, N. (2006). Hrvatski regionalni grč. Panliber: Zagreb

Šimunović, I. (1994). Regionalni sindrom Hrvatske, u: M. Maras (ur.). Prilozi za hrvatski nacionalni program: promišljanje identiteta. Zagreb: Matica hrvatska, 43-49.

Turk, I. (2008). Promjena broja stanovnika Karlovačke županije od 1857. do 2001. godine, Društvena istraživanja, 17 (3): 437-461.

Wertheimer-Baletić, A. (2005). Determinante reprodukcije stanovništva Hrvatske u drugoj polovici 20. stoljeća, u: D. Živić, N. Pokos i A. Mišetić (ur.). Stanovništvo Hrvatske - dosadašnji razvoj $i$ perspektive. Zagreb: Institut društvenih znanosti Ivo Pilar, 9-37.

Zakon o prebivalištu, Narodne novine, 144/12, 158/13.

Živić, D. (1999). Promjene u dinamici i razmještaju prognaničko-izbjegličkog kontingenta u Republici Hrvatskoj od sredine 1991.do sredine 1998. godine, Društvena istraživanja, 8 (5-6): 767-791.

Živić, D. (2014). Prisilne (ratne) migracije kao čimbenik demografskih promjena u Hrvatskoj (1991.-2011.), u: A. Akrap, I. Čipin i M. Strmota (ur.). Zbornik radova znanstvenog skupa Demografija u Hrvatskoj. Zagreb: Ekonomski fakultet, 297-317. 


\section{IZVORI}

Migracija stanovništva Republike Hrvatske u 2004., Priopćenje 7.1.2., Državni zavod za statistiku, Zagreb, 2005.

Migracija stanovništva Republike Hrvatske u 2013., Priopćenje 7.1.2., Državni zavod za statistiku, Zagreb, 2014.

Popis stanovništva, domaćinstava, stanova i poljoprivrednih gospodarstava 1991., Tablica 1.1.6, Stanovništvo prema migracijskim obilježjima, Državni zavod za statistiku, Zagreb.

Popis stanovništva, kućanstava i stanova 2001., Državni zavod za statistiku, Zagreb, www. dzs.hr.

Popis stanovništva, kućanstva i stanova 2011., Državni zavod za statistiku, Zagreb, www. dzs.hr.

Prirodno kretanje stanovništva Republike Hrvatske u 2013., Priopćenje 7.1.1., Državni zavod za statistiku, Zagreb, 2014.

Vitalna statistika RH, tablogrami, 2001.-2010., Državni zavod za statistiku, Zagreb. 


\title{
Current Migration Characteristics of Statistical Units of the Republic of Croatia
}

\author{
Sanja Klempić Bogadi, Ivan Lajić
}

\begin{abstract}
SUMMARY
The paper analyzes the basic demographic processes in the Republic of Croatia (NUTS 1), in its statistical macro-regions (NUTS 2) and counties (NUTS 3) in the inter-census period from 2001 to 2011. The theoretical part discusses the optimal structure and the establishment of statistical macro-regions, as well as the impact of demographic factors on their formation. The authors are critical of the quality and content of certain demographic categories set in the last census and their incomparability with previous censuses. Medium-intensity depopulation is still continuing; however, a large part of the Croatian territory is affected by this unfavourable characteristic of the overall population trend. Namely, in the last decade of the intercensus period, only the City of Zagreb and Zagreb County in Continental Croatia recorded an increase in population, while in Adriatic Croatia such a case was found only in the Zadar and Istria Counties. Both components of the overall population trends in Croatia - natural change and net migration - bear a negative denominator. Only two of twenty-one NUTS 3 units showed natural increase (the Split-Dalmatia and Dubrovnik-Neretva Counties), while the other counties, even the immigration ones, registered natural population decrease. It is obvious from migration data that Croatia has polarized to Zagreb and its surroundings as the economic and demographic centre of the country, and to the coastal counties that, for the most part, still have an economically attractive tourism-based economic development and migration attractiveness to some extent. Most Continental Croatian counties consist of poorly developed, peripheral areas of depopulation and demographic decline in general.
\end{abstract}

KEY WORDS: Croatia, NUTS, migration, depopulation, natural change 